Portland State University

PDXScholar

Spring 7-25-2013

\title{
Natural Area Stewardship Volunteers: Motivations, Attitudes, Behaviors
}

Corinne Handelman

Portland State University

Follow this and additional works at: https://pdxscholar.library.pdx.edu/open_access_etds

Part of the Environmental Health and Protection Commons, Natural Resources Management and Policy Commons, and the Other Psychology Commons

Let us know how access to this document benefits you.

\section{Recommended Citation}

Handelman, Corinne, "Natural Area Stewardship Volunteers: Motivations, Attitudes, Behaviors" (2013). Dissertations and Theses. Paper 1058.

https://doi.org/10.15760/etd.1058

This Thesis is brought to you for free and open access. It has been accepted for inclusion in Dissertations and Theses by an authorized administrator of PDXScholar. Please contact us if we can make this document more accessible: pdxscholar@pdx.edu. 
Natural Area Stewardship Volunteers:

Motivations, Attitudes, Behaviors

by

Corinne Handelman

A thesis submitted in partial fulfillment of the requirements for the degree of

Master of Science

in

Environmental Science and Management

Thesis Committee:

Marion Dresner, Chair

J. Alan Yeakley

Monica Paulson Priebe

Portland State University

2013 


\begin{abstract}
To better understand the value of those who engage in environmental stewardship of natural areas, we studied volunteer steward's motivation to participate, their sustainable behaviors and attitudes toward stewardship-related constructs. Specifically, we designed and conducted a survey of volunteers who work as stewards in urban natural areas in Portland, Oregon. We hypothesize that as volunteer frequency increases: participants will be more motivated to participate for environmental reasons, volunteers will be more likely to feel a strong connection to the stewardship site, participants will be more likely to engage in public proenvironmental behaviors, and their level of environmental literacy will increase. Participants were sampled using a face-to-face survey methodology over the course of late winter and spring of 2012 during 18 different Portland Parks and Recreation sponsored stewardship events. We examined the motivations, attitudes and behaviors of the volunteers, and devised appropriate management implications for those organizing volunteer efforts. We equated a three-tiered typology of environmental literacy, based upon the frequency of volunteer participation, and analyzed our survey data using a principal component analysis, generalized linear models, and a qualitative coding analysis. The most frequent participants showed a higher likelihood of participation in public environmental behaviors, whereas participants at all frequency levels were also likely to participate in private environmental behaviors, such as removing invasive plants in one's yard. Volunteers across all frequencies of participation were motivated to engage in


stewardship events by a desire to help the environment. By understanding volunteers' motivations and linked behaviors, park managers may gain insights about the recruitment, retention, and messaging of volunteers upon whom they may depend to achieve restoration goals. We recommend considering volunteers' motivations and benefits derived from participation in messaging to recruit and retain volunteers. Additionally, park managers should take advantage of educational opportunities linked to stewardship events, such as training programs and chances for volunteer mentorship. 


\section{Acknowledgments}

I would like to thank Dr. Marion Dresner, my research advisor, for her inspiration and guidance throughout this project. Without her this project would not have come to fruition.

Thanks to Portland Parks and Recreation for encouraging this study and particularly Rachel Felice, Susan Hawes, and Marissa Dorais for giving valuable feedback. Thanks to all of the wonderful park volunteers who participated in the survey.

Thanks to my committee members Dr. Monica Paulson Priebe and Dr. Alan Yeakley for providing generous feedback and encouragement. Thanks to Dr. Yangdong Pan for assistance with data analysis and interpretation. Thanks to Dr. Jeff Gerwing for reminding me to tell a story through my findings.

Thanks also to Steven Braun, Kerissa Fucillo, and Jill Van Winkle who were integral to the development of this research project. Thanks to Sara Copp for input on management interpretations. Also thanks to Larissa Figley, who helped conduct surveys.

Nicole Alfafara reminded me to keep my standards high and produce the best work possible. Tim Elder was a constant sounding board and provided moral support throughout the process. Pablo Barreyro provided encouragement and pushed me forward throughout this project.

Thanks to my parents Albert Handelman, Kathy Lebs, and Paula Handelman for encouraging me to pursue my passion and for reminding me to see the bigger picture.

Thanks to my friends, especially Alyssa Burgo and Morgan Holman, who are always by my side, even if they are far away.

There are many others who are not named here, and I am so grateful to have such a loving support system. 


\section{Table of Contents}

ABSTRACT I

ACKNOWLEDGMENTS III

TABLE OF CONTENTS IV

LIST OF TABLES VI

LIST OF FIGURES VII

INTRODUCTION 1

OVERVIEW

INTRODUCTION TO THE STEWARDSHIP ORGANIZATION

STEWARDSHIP VOLUNTEER IMPACTS

MOTIVATIONS TO VOLUNTEER $\quad \mathbf{7}$

ATTITUDE AND BEHAVIOR VARIABLES 9

ENVIRONMENTAL LITERACY CONSTRUCTS

STUDYING VOLUNTEER ATTITUDES AND BEHAVIORS 17

RESEARCH HYPOTHESES

\begin{tabular}{lr} 
METHODS & 20 \\
\hline
\end{tabular}

SURVEY DEVELOPMENT AND IMPLEMENTATION

DATA ANALYSIS $\quad 24$

\begin{tabular}{lr} 
RESULTS & 27 \\
\hline
\end{tabular}

$\begin{array}{lr}\text { ALL VOLUNTEERS } & \mathbf{2 7}\end{array}$

MOTIVATIONS TO PARTICIPATE $\quad 29$

ENVIRONMENTAL LITERACY GROUPS

ASSESSING VARIATION OF SURVEY RESPONSES

FREQUENCY OF VOLUNTEERING

DEMOGRAPHIC INFORMATION

\begin{tabular}{lr} 
DISCUSSION & 46 \\
\hline
\end{tabular}

OVERALL FINDINGS $\quad \mathbf{4 6}$

ENVIRONMENTAL LITERACY CONSTRUCTS $\quad \mathbf{4 7}$

MOTIVATIONS TO PARTICIPATE $\quad \mathbf{4 9}$

ATTITUDE-BEHAVIOR RESPONSES

STEWARDSHIP ENGAGEMENT IN THE COMMUNITY $\quad \mathbf{5 4}$

POTENTIAL SURVEY MEASUREMENT ERRORS 
APPENDIX C: EVENT INFORMATION

80

APPENDIX D: SUMMARY STATISTICS OF ATTITUDES AND BEHAVIORS

APPENDIX E: FULL GENERALIZED LINEAR MODEL OUTPUTS

87

APPENDIX F: HUMAN SUBJECTS APPROVAL

90 


\section{List of Tables}

Table 1: Environmental literacy constructs, including their associated attitudes and behaviors, which are interpreted as a factor of volunteer frequency (pg. 16)

Table 2: Behavioral questions given to all volunteers, who responded that they either do or do not engage in these behaviors (pg. 22)

Table 3: Attitude questions and associated conceptual constructs, with responses given on a 5-point Likert scale (pg. 22)

Table 4: Qualitative coding options for the open-ended survey question assessing motivations to volunteer and the impact from volunteering (pg. 24)

Table 5: Response replacements to include first time volunteer attitudes in our data analysis (pg. 25)

Table 6: Volunteer responses to the open-ended question, "What impact has working on environmental restoration had on you?" (pg. 31)

Table 7: Overlapping benefits derived from volunteer stewardship, as given in responses to our open-ended question (pg. 32)

Table 8: The strongest eigenvectors in Principal Component 1 and Principal Component 2 (pg. 36)

Table 9: Generalized Linear Model outputs of behavioral predictors of attitude responses that are indicative of the three levels of environmental literacy and volunteer frequency (pg. 39)

Table 10: Demographic information of respondents split based on the three levels of volunteer frequency (pg. 45) 


\section{List of Figures}

Figure 1: Locations of parks surveyed in Portland, Oregon (pg. 20)

Figure 2: Responses from all volunteers to behavioral questions with $80 \%$ agreement or higher (pg. 28)

Figure 3: Responses from all volunteers to attitude questions with the highest level of variation within responses (pg. 29)

Figure 4: Volunteer responses to the forced-choice question, "Which is the most compelling reason you volunteered here today?" (pg. 31)

Figure 5: A plot depicting our two principal components with the highest degree of explanatory power (pg. 37)

Figure 6: Biplot results for our principal component analysis, displaying our first two principal components, as well as the primary eigenvectors explaining this variance in our data (pg. 38)

Figure 7: Responses from entry level volunteers to the attitude "I care about the environment" and behavior "I talk to neighbors about restoration of natural places" (pg. 40)

Figure 8: Responses from ownership level volunteers to the attitude "I care about or for the environment" and behavior "I treat my yard as wildlife habitat" (pg. 41)

Figure 9: Ownership level volunteer responses to the attitude "I feel a connection to this site" and behavior "I contact local elected officials to advocate for natural areas" (pg. 41)

Figure 10: Empowerment level volunteer responses to the attitude "I feel a connection to this site" and behavior "I talk to neighbors about restoration of natural areas" (pg. 42)

Figure 11: Responses from empowerment level volunteers to the attitude "I am interested in becoming a volunteer leader" and behavior "I contact local elected officials to advocate for natural areas" (pg. 43)

Figure 12: Empowerment level volunteers responses to the attitude "I feel like my work here contributes to a solution to current environmental problems" and behavior "I talk to my neighbors about restoration of natural areas" (pg. 43) 


\section{Introduction}

\section{Overview}

Stewardship in natural areas is more than an action; it is a display of an ethic that shows concern for the environment. While stewardship can mean a variety of things, we use this term to describe volunteer-based ecological restoration. For example, "Volunteers help to build and maintain trails, restore ecosystems by clearing exotic plant species and planting native species, monitor and identify endangered species and their habitats and publicize the environmental message through newsletters, workshops and demonstration projects" (Ryan et al. 2001, pg. 629). Practitioners who seek to define stewardship acknowledge four components to stewardship, which include an ethic or responsibility, motivations to participate, the process itself, and outcomes (Romolini et al. 2012, pg. 7). Many natural areas are becoming damaged by human impacts such as the introduction of invasive species, urban encroachment, and trail degradation. Stewardship is one way that nonscientists can give back to these ecosystems, by removing invasive species, maintaining park trails, and replanting native species. By volunteering for stewardship, there are likely benefits to the ecosystem, as well as to the participants themselves and to society. These benefits derived from participating feed back as motivations to return as a stewardship volunteer (Grese et al. 2000). Natural area stewardship volunteers have associated attitudes and behaviors that can describe the ethic created by participating in stewardship events (Worrell and Appleby 2000). 
We believe that a stewardship ethic is based on diverse variables. We seek to study the association among motivation to participate, frequency of volunteering, attitudes about the environment, and sustainable behaviors. Those who participate in stewardship are likely to build a connection or attachment to their volunteer site (Gooch 2002; Ryan 2005), and display a sense of responsibility for their local environment as they can see a transformation over time as a result of their actions (Ryan 2005). Many who volunteer are motivated by a desire to do meaningful work that makes a difference in environments that need restoration (Kaplan 2000; Shandas and Messer 2008). As volunteers participate more frequently, it is likely that they are inspired to further protect natural areas. This is displayed by associated sustainable behaviors, which they apply in other areas of their life (Ajzen and Fishbein 1977). Volunteers may appreciate social and community-building aspects to volunteer stewardship, and use their participation as a platform to engage others in environmental restoration (Wolf et al. 2011). Additionally, environmentally sustainable attitudes can be fostered over time, as a result of their volunteer participation in stewardship (Grese et al. 2000).

\section{Introduction to the Stewardship Organization}

Portland Parks and Recreation (PPR) manages diverse park spaces located within the Portland urban area. These range from natural parks that include mixed coniferous forest or wetland habitats to highly managed parks, and are spread across different neighborhoods through the city. Since local communities can build 
identities around natural areas, and many residents may feel compelled to volunteer in the parks to give back to their community or help maintain the natural environment, it is important to understand the specifics of the area being studied. Volunteer stewardship is an overlay of place-based environmental activism (Ryan 2005; Johnson 2004) in natural park spaces in Portland.

A large number of people in urban areas, such as Portland, participate in stewardship activities within local parks. Many agencies that manage natural areas use stewardship volunteers to help them accomplish restoration goals, as these volunteer efforts contribute towards the recovery of degraded ecosystems (Shandas and Messer 2008). These volunteers who participate in restoration activities can be referred to as natural area stewards. In Portland, there are several organizations such as PPR that engage public groups in structured stewardship activities, such as the removal of invasive species from green spaces, replanting native species, trail maintenance, and other restoration projects. Many groups who conduct stewardship activities in Portland's park spaces work in coordination with PPR to organize these volunteer events.

The PPR stewardship volunteer program was established over 15 years ago. Stewardship volunteers began as loosely formed groups working within the parks, before a formal structure existed within the city. The program became cemented in city policy via the Parks 2020 Vision document, which was created in 1999 as a 20year parks plan. One of the primary goals listed within this document is to "Engage 
residents as stewards of Portland's parks and recreation system to help preserve the legacy for future generations (Portland Parks and Recreation 1999, pg. 28)." This not only emphasizes the need for preservation, but uses the language of "stewards", which connotes more than the term "volunteers" (Worrell and Appleby 2000). This document specifically highlights civic involvement as a means to increase capacity to get work done, such as invasive species removal or tree planting in parks, which can be categorized as restoration. The document defines stewardship as one of its guiding principles, stating "Portland residents value and care for public spaces and resources, recognize and respect the intrinsic values of all organisms, and are stewards for all the elements of the built and natural world, sustaining them for future generations (Portland Parks and Recreation 1999, pg. 7)."

As of a 2009 progress report document, PPR is achieving their stewardship goals ahead of the schedule laid out in the Parks 2020 Vision. Volunteers logged almost 460,000 hours in 2008, which was an increase of 37,000 hours from 2003 (Portland Parks and Recreation 2009). This means that volunteers alone work almost one third of the number of hours that PPR staff work. During 2010-2011, the PPR volunteer program tallied almost 454,000 hours, equivalent to $\$ 5$ million in value.

During structured interviews conducted by Steven Braun, a PhD student at Portland State University, PPR volunteer stewardship coordinators acknowledge a high degree of civic involvement in Portland (S. Braun, personal communication, 2012). PPR stewardship coordinators also state that one benefit of having volunteer 
opportunities is providing those volunteers with a "friendly face" for their government, offering opportunities for citizens to participate along with government in protecting natural areas that have a high value to citizens. The PPR program provides two or more volunteer events per week at different natural park spaces around the city. Each park typically has one event per month, and larger natural areas, such as Forest Park, have up to four events per month. These stewardship events are run in coordination with networks of "Friends of Parks" groups using Memorandums of Understanding to share visions for the future of those natural areas and delineate responsibilities for the volunteer events.

\section{Stewardship Volunteer Impacts}

There is a strong ethic of stewardship and general volunteerism in Portland (Johnson 2004). The Bureau of Labor Statistics and Census Bureau has collected data on volunteering, and has recorded percentages of adults 16 years or older who volunteer through one or more groups. Volunteering through organizations helps build a strong sense of civic engagement and community building to address local needs. According to this study, the Portland metropolitan area has the second highest rate of volunteering out of 51 metropolitan areas surveyed, with $36.2 \%$ of

adults volunteering (Johnson 2004). They determined that some of the main drivers of volunteerism were a sense of responsibility for the public good, existence of structures and processes that facilitate community engagement, access to relevant information, and access to education (Johnson 2004). 
Agencies such as PPR rely heavily on volunteer efforts to reach their organizational goals, such as restoration achievements or completion of volunteer work hours. Retaining current volunteers is beneficial because those volunteers have already received the informal training necessary to be effective in their restoration efforts. Returning volunteers might also be well versed in the goals of the organization, and familiar with the natural area where they work. These impacts of return volunteers can therefore be beneficial to the individual and to the organization, as a stronger relationship between the volunteer and their agency is formed. Prolonged engagement in stewardship can also increase environmental consciousness of members in a community (Shandas and Messer 2008). In some ways, the benefits of continual volunteering may extend to the larger community, beyond the participants and the volunteer organization. Volunteers are typically more politically engaged than non-volunteers as they become socialized to the needs of the causes they support (Wilson 2000). For stewardship organizations, this can create long-term benefits such as secured budgets or policies that support their goals, if their volunteer force is willing to become political advocates to support environmental causes (Ryan et al. 2001).

Volunteer restoration activities involve active relationships with specific natural areas. This relationship may create a feeling of connection or attachment to the natural area (Ryan 2005; Gooch 2002). A better understanding of personal motivations and impacts from volunteer stewardship is important to elucidate likely 
positive consequences such as: feeling that their work is useful, learning new skills, having a chance for personal reflection, and other personal and social outcomes (Grese et al. 2000). Currently, these positive outcomes are not well understood, and the benefits derived from volunteering are likely to play a role in motivation to return as a volunteer (Grese et al. 2000). Volunteering in local parks may inspire volunteers to further protect natural areas by generating an environmental ethic (Leopold 1949).

Public natural resource agencies and non-governmental organizations may rely on volunteers to further the cause of protecting and restoring the natural environment. The environmental benefits of the collective work done over time by volunteers are sometimes made explicit (i.e., we cleared 5 acres of English ivy and planted 200 native saplings at Forest Park this year), are sometimes left vague (i.e., removing invasive species helps restore habitat for wildlife), and sometimes are not explained. Natural area managers who are working with volunteers in stewardship activities can benefit from knowing more about what motivates volunteers to participate, what information to give the people who come, how to retain volunteers, and how to best provide continued programming to enhance the volunteers' experience.

\section{Motivations to Volunteer}

Volunteers engage in the purposeful act of donating one's time and energy on behalf of a cause. Volunteers can be motivated to participate for a wide variety of reasons, 
and many motivations for stewardship volunteers are based in concerns for the environment. Volunteer motivations range from gaining a sense of satisfaction from doing something tangible on behalf of the environment, to feeling like volunteering gives time for personal reflection and contributes to personal well-being (Ryan et al. 2001). Participation in volunteer activities also provides the satisfaction of meeting people with similar interests and making new friends (Manzo and Weinstein 1987). Stewardship contributes to satisfaction gained from volunteer activities associated with physical activity, being outside, and giving back to park spaces that volunteers use for recreation or other purposes (Bruyere and Rappe 2007). Some volunteers are driven by a desire to advance their careers or to learn more about local environments (Bruyere and Rappe 2007). Participants may have social goals, such as being a part of their community and socializing, as well as commitments to environmental restoration (Wolf et al. 2011).

With all of these potential motivations, it can be a challenge to learn what the primary drivers are for those who participate in an activity such as stewardship, which has environmental, social, and educational components. Stewardship volunteering may indicate a combination of motivations, such as caring for nature and feelings of social belonging (Pretty et al. 2011). The distinction between this mixture of motivations and a single motivational factor might be a display of value. If volunteers hold multiple motivations, but cite one specifically, it might be the value they wish to display through their volunteer actions (Ryan et al. 2001). The motives of volunteers in natural areas are thought to differ somewhat from general 
volunteers, such as those who volunteer in community groups, social services, schools, or religious institutions. The results of the efforts of stewardship volunteers are typically visible and tangible, which can serve as a distinction from general volunteerism, where outcomes may be less concrete (Pretty et al. 2011).

Volunteer motivations may differ over time as commitment to an organization becomes ingrained in the volunteer experience. Volunteering for stewardship itself is a behavior that displays a concern for the environment, so while there may be a variety of motivations to begin volunteering, the environmental impacts might be especially important to retain volunteers. This leads us to believe that environmentally sustainable attitudes and behaviors in volunteers can be fostered over time, regardless of their initial outlook. Pro-environmental perspectives can motivate volunteers to return to stewardship events (Grese et al. 2000). There may also be larger impacts, as environmental attitudes and behaviors, such as advocating for environmental restoration, may bring others into the stewardship community and further educate new participants about the potential benefits of stewardship (Johnson 2004). These positive impacts can be motivational for participants to return as volunteers if they wish to produce such meaningful outcomes.

\section{Attitude and Behavior Variables}

There are several primary variables that define environmental attitudes and behaviors for the purposes of this study. To study behaviors, we draw distinctions 
between public and private pro-environmental actions (Stern 2000). These behaviors may have different levels of impact on the individual and on the surrounding community. Additionally, stewardship volunteering itself is a public pro-environmental behavior, so by examining the benefits derived from participating, we may further understand the greater impacts of participation. We expect that as volunteer frequency increases, so will participation in public proenvironmental behaviors (Ajzen and Fishbein 1977).

Positive experiences in natural environments may promote pro-environmental behaviors. Experiences in natural environments may shape perception of the importance of nature, and since volunteering is an active experience, there are associated behavioral changes that result from stewardship. These are likely to be pro-environmental behaviors, which are defined as "behavior undertaken to preserve or improve environmental quality" (Manzo and Weinstein 1987, pg. 674). Volunteers who engage in stewardship take away attitudes and behaviors about the environment that they apply in other areas of their life. Through continued engagement in stewardship, volunteers may exhibit more environmentally sustainable behaviors (Ajzen and Fishbein 1977).

Environmentally sustainable behaviors can be classified in various ways. Some behaviors indicate environmental activism, such as public advocacy or talking to others about environmental causes. Other behaviors are personal or private, and can include daily decisions about resource usage or purchasing decisions (Stern 
2000). Each of these types of behaviors may be linked to volunteering for environmental stewardship; public behaviors may include advocating for natural areas and private behaviors can include removing invasive species on their own property. Both of these types of behaviors are considered environmentally responsible, though they have differing impacts (Stern 2000). Private proenvironmental behaviors reinforce positive environmental attitudes within an individual. In addition to reinforcing environmental attitudes, public behaviors may raise community awareness about environmental issues or help to involve others in stewardship activities.

Based on the literature, five categories of influence to environmental attitudes related to stewardship were determined: place-based attachment, environmental reasons, social or community reasons, education, and "giving back". An appreciation for nature can be associated with many nature-based activities. While volunteering establishes a strong place-based connection, other recreational activities can predict environmentally friendly attitudes (Thapa 2010). Recreational users who reported participating in activities that show appreciation for nature were likely to have positive environmental attitudes, such as understanding human impacts on the environment. These attitudes had a positive effect on environmental behaviors, including actions ranging from political activism to private sustainable decisions (Thapa 2010). Those who participate in these recreational activities such as hiking or taking photographs in nature might use their interest in natural areas as a motivational basis to volunteer. These recreational users who report pro- 
environmental attitudes might be motivated to take care of the natural areas that they use, and express their personal values about the environment through stewardship volunteering (Bruyere and Rappe 2007). We see a similar relation to volunteer participation in natural areas, and therefore believe that as volunteer frequency increases, so will an appreciation for the environment.

Past studies on stewardship volunteers have found that volunteer's attitudes, behaviors, and motivations change over the course of their involvement in stewardship activities (Ryan et al. 2001). It has also been shown that long-term volunteer commitment allows individuals to develop a connection to specific places (Ryan et al. 2001). A significant relationship exists between volunteers' experience working in the parks and the degree of place attachment (Ryan 2005). Volunteers who feel highly connected to a park viewed park management positively, and were in support of active management to maintain native plant communities. In contrast, visitors to the park with a passive involvement had a lower degree of place attachment, and favored a more ornamental plant appearance for the park (Ryan 2005). This attitude of attachment to place can be reinforced through participation in stewardship activities.

Social benefits and positively impacting a surrounding community has been shown to motivate volunteers and increase their likelihood of returning (Asah and Blahna 2012). Socializing may also be seen as a personal benefit, and this might be important particularly for new volunteers seeking a network of those with similar 
interests (Wolf et al. 2011). Stewardship can build green social communities through personal interactions and create visible change in local ecosystems (Johnson 2004; Grese et al. 2000). In this sense, social belonging may influence volunteer participation, and volunteers may build a like-minded community of stewards over time.

Stewardship has many educational aspects as volunteers learn new knowledge and skills that can be applied to other areas of their lives (Mundel and Schugurensky 2008). Volunteers may display a desire for further education, particularly on topics such as plant identification, human impacts on natural areas, or restoration ecology. We expect there to be a high level of interest in educational components to volunteering in stewardship, particularly in less frequent volunteers. This might be the case since long-term participants have already learned many of these aspects of stewardship (Miles et al. 2000).

Our final attitude variable for this study was "giving back", which can be seen as an altruistic motivation to participate in stewardship. This attitude specifically displays a value, which is slightly different from our other tested variables. While many volunteers may be motivated by personal reasons, there is a strong sense of desire to help the environment or local communities by participating in stewardship (Shandas and Messer 2008). Volunteers feel that this work is meaningful, hold proenvironmental attitudes, and can be empowered that their participation makes a difference (Kaplan 2000). This attitude construct may be combined with our other 
variables, such as education or environmental motivations to participate, as motivations for giving back are typically based on a sense of accomplishment as a result of work done over time (Ryan 2005). We anticipate more frequent volunteers to have a strong desire to give back through their work in stewardship, as they have seen the impacts of their work.

\section{Environmental Literacy Constructs}

Environmental literacy is defined as the capacity to perceive and interpret the relative health of environmental systems and take appropriate action to maintain, restore or improve those systems (Disinger and Roth 1992). Environmental stewardship events inherently include an informal learning component. Although these activities are not educational in a traditional pedagogical sense, they can generate new skills, knowledge, and attitudes. Volunteers may learn complex new skills and can then apply them, gaining explicit knowledge, in an applied manner (Mundel and Schugurensky 2008). Volunteers may also learn skills such as community organizing, particularly if they choose to take a leadership role within an event. These social skills are important to many volunteers, and satisfaction from community involvement may result (Wilson 2000). While neither of these learning experiences is explicit in the purpose of a stewardship event, there are direct benefits to volunteers. 
The frequency of participation in volunteer events has significant effects on learning, and those who volunteer more frequently learn a wider variety of skills and knowledge (Astin and Sax 1998). Specific to stewardship activities, volunteers may learn plant identification, information on removing invasive species, and how native plants are beneficial to local ecosystems. Volunteers may also be given different opportunities based on their commitment to volunteering. For example, experienced volunteers may be allowed to take a leadership role within an event, by guiding new volunteers. In this sense, volunteers may be given different educational opportunities, and more experienced volunteers may pass on their knowledge to those who volunteer less frequently (Miles et al. 2000). This gain of knowledge, and the desire to take action to improve environmental system health is inherent in stewardship, and therefore we decided to apply this conceptual model to our study of stewardship volunteers.

Environmental literacy develops over time and can be categorized into levels based on individual knowledge. These levels of engagement have been thought to inform an individual's behavior in a linear manner as they develop (Hungerford and Volk 1990). Based on this linear relationship, someone's level of environmental literacy helps explain his or her environmental behaviors and attitudes. In this environmental literacy construct, entry-level variables include an empathetic perspective towards the environment. Ownership-level variables include in-depth knowledge and personal investment in the issues and the environment. Empowerment level variables include knowledge of pro-environmentally 
responsible behaviors, and the perception of having the skills and ability to help resolve an environmental issue.

This environmental literacy model lends itself to a hierarchy of attitudes and behaviors, which we relate to the frequency of a volunteer's involvement in stewardship activities (entry level, infrequent volunteer; ownership, mid-range of participation; empowerment, frequent volunteer participation) (Marcinkowski 2004). We used this hierarchy of involvement because it combines and scales different attitudes and behaviors in a simple and meaningful manner (Table 1). This model can be used to test how well each level of involvement describes our findings for each level of volunteer frequency. We assume that the frequency of participation in stewardship volunteering provides different experiences for volunteers, and leads to different attitude and behavioral outcomes.

Table 1: Environmental literacy constructs, including their associated attitudes and behaviors, which are interpreted as a factor of volunteer frequency (Adapted from Marcinkowski 2004).

\begin{tabular}{|l|l|l|l|}
\hline $\begin{array}{l}\text { Environmental } \\
\text { Literacy Level }\end{array}$ & $\begin{array}{l}\text { Volunteer } \\
\text { Frequency }\end{array}$ & Attitudes & Behaviors \\
\hline Entry & $\begin{array}{l}\text { First time, or } \\
\text { annually } \\
\text { annes }\end{array}$ & $\begin{array}{l}\text { Social \& community-based } \\
\text { care for environment } \\
\text { annually }\end{array}$ & $\begin{array}{l}\text { Private } \\
\text { environmental } \\
\text { behaviors }\end{array}$ \\
\hline Ownership & $\begin{array}{l}\text { 3-10 times about the environment } \\
\text { public } \\
\text { environmental } \\
\text { behaviors }\end{array}$ \\
\hline Empowerment & $\begin{array}{l}\text { Over 10 } \\
\text { times } \\
\text { annually }\end{array}$ & $\begin{array}{l}\text { Connection to volunteer site, } \\
\text { feeling that work makes a } \\
\text { difference, a stewardship ethic }\end{array}$ & $\begin{array}{l}\text { Public } \\
\text { environmental } \\
\text { behaviors }\end{array}$ \\
\hline
\end{tabular}




\section{Studying Volunteer Attitudes and Behaviors}

Volunteer attitudes, behaviors, and motivations are often assessed through surveys. The Green Cities Research Alliance near Seattle, Washington surveyed volunteers in a range of volunteer activities countywide. Volunteers' motivations and the influence of these motivations in the frequency of participation in urban conservation activities were analyzed (Asah and Blahna 2012). Overall, they found that volunteers' frequency of participation was motivated by personal and social benefits (i.e. meeting new people) rather than environment-related reasons. Environmental motivations were predictors of participation once personal and social motivations were met. They conclude that environmentally focused strategies for motivating more frequent participation were not likely to be as effective as appeals to personal and social motivations for urban conservation (Asah and Blahna 2012). Understanding motivations for participating in natural area stewardship is important for practical reasons. The results can help agencies better target their message, and provide them with information about linking the work on the site with responsible recreational practices in parks and other natural areas.

Surveying allows for stewardship volunteers to give responses on a variety of topics, including the environmental and social aspects of volunteer events. It also gives a concrete outcome to be reported back to the volunteer organization, so that they may better understand the attitudes of their volunteers and be able to fulfill their needs. Past studies have been conducted using a variety of survey techniques, including mail-in surveys and face-to-face interviews (Bruyere and Rappe 2007; 
Ryan et al. 2001). Generally, lower response rates are found in mail- or phonebased surveys in comparison to in-person surveys (Groves et al. 2004).

Additionally, in-person surveys might allow for more thorough and thoughtful answers by respondents, as the interviewer may provide clarification or prompting. This may imply some bias in responses, but each survey methodology has drawbacks, and consistency in interviewer behavior can minimize these impacts. 


\section{Research Hypotheses}

We designed and implemented a survey in Portland, Oregon in order to understand what motivated volunteers to engage in natural area stewardship, and to better understand the range of motivations, attitudes, and behaviors associated with work in natural areas, particularly as they relate to frequency of participation.

- We hypothesize that as volunteer frequency increases, participants will be more motivated to participate for environmental reasons

- We hypothesize that more frequent volunteers will be more likely to feel a strong connection to the stewardship site

- We hypothesize that as volunteer frequency increases, participants will be more likely to engage in public pro-environmental behaviors

- We hypothesize that as stewardship volunteer frequency increases, so will their level of environmental literacy 


\section{Methods}

\section{Survey Development and Implementation}

We sampled every unique volunteer event for PPR between February and June of 2012. PPR often had multiple events at the same site over time, we chose to sample each work site only once during that period. Our sampling technique included a means to sample volunteers without bias. At the start of the event, each work crew leader would make an announcement about the study we were conducting, and would indicate who we were in the group. After about an hour of work, we would begin the survey by approaching every other volunteer in each working group and asking if they would be willing to answer the questions on our survey. Only volunteers who were age 18 or older were asked to participate in the survey.

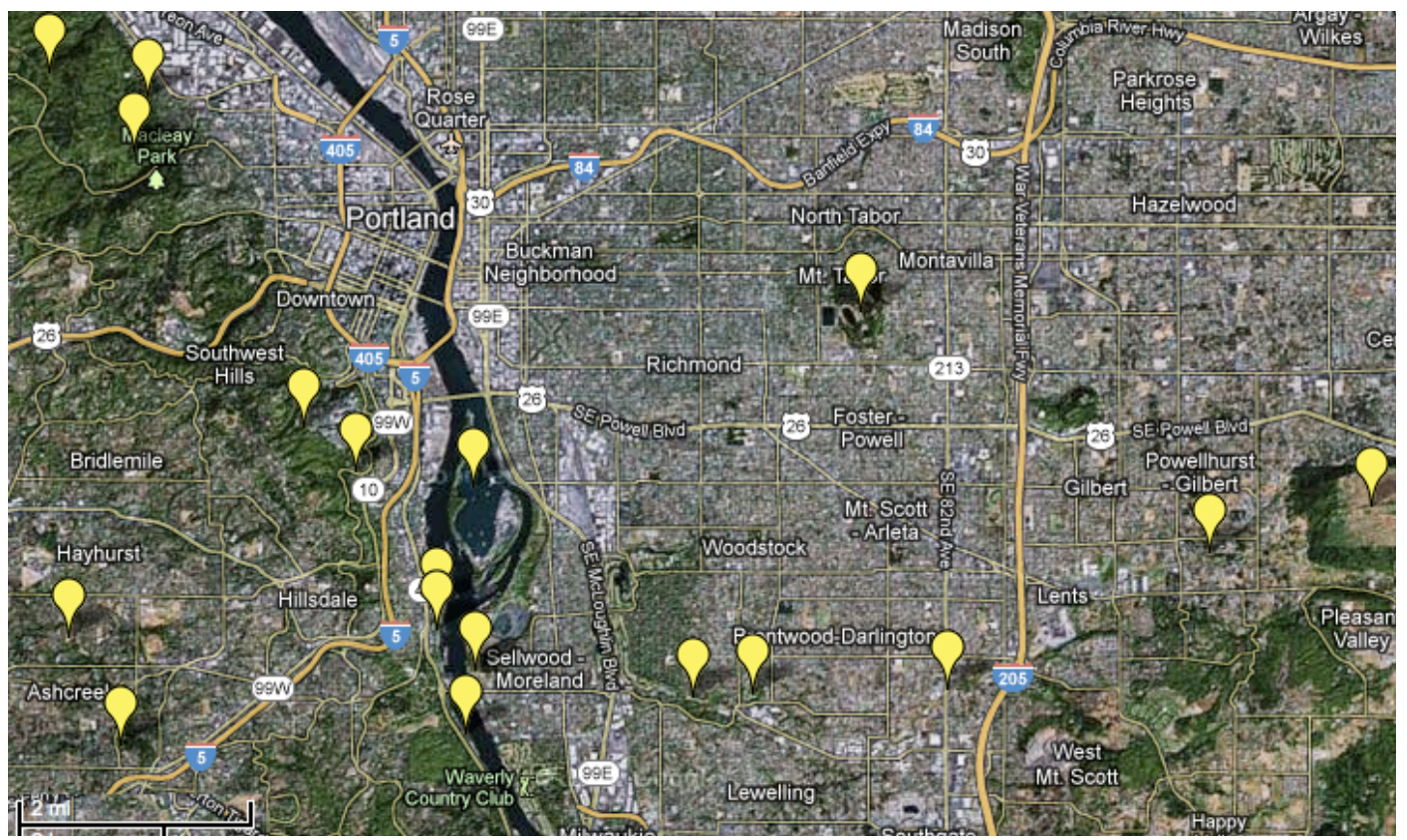

Figure 1: Locations of parks surveyed in Portland, OR (image from Google Earth). All parks were under natural areas management, and utilized stewardship volunteers to achieve restoration goals. 
Volunteers were given the choice of completing the survey orally while the researcher filled out the questionnaire or completing the survey independently while the researcher performed the work on their behalf. Our intention was to conduct as many questionnaires as possible within the 3-hour event. Altogether, we sampled a total of 18 events (131 individuals; a response rate of $52.4 \%$ of all volunteers at events) in Portland (Figure 1).

The survey was written to assess volunteer motivations, attitudes, behaviors, and other information pertinent to the PPR volunteer stewardship program. Our survey was based in part on the Green Cities Alliance survey of stewardship (Asah and Blahna 2012). Several open-ended questions allowed participants to comment further on their restoration experiences. There were different sections for first time participants and for frequent participants. Altogether, the questionnaire contained 48 questions, and included questions to solicit demographic information including gender, income, and age, and asked about travel time to the site.

Motivations to volunteer were primarily assessed using two metrics, a forced-choice question, "Which is the most compelling reason you volunteered here today?" with seven response options, and an open-ended question, "In your own words, what impact has working on environmental restoration had on you?" Response options for the forced choice question were: environmental reasons, socializing, community improvement, being outside, educational reasons, networking or resume building, and because the respondent uses the park. Volunteer behaviors were assessed 
through nine questions asking what behaviors the participant currently engages in, with responses limited to yes or no (Table 2). Volunteers' attitudes regarding environmental, community, and other values linked to stewardship were evaluated using responses to ten different questions (Table 3).

Table 2: Behavioral questions given to all volunteers, who responded that they either do or do not engage in these behaviors.

\begin{tabular}{|l|l|}
\hline Do you currently engage in the following practices? & Public or Private Behavior \\
\hline Planting natives in your own yard & Private \\
\hline Removing invasive species in your own yard & Private \\
\hline Using environmentally friendly household products & Private \\
\hline Using pesticide in your own yard & Private \\
\hline Treating your yard as wildlife habitat & Private \\
\hline Conserving water in your yard or household & Private \\
\hline Using natural park spaces in your free time & Private \\
\hline Contacting local elected officials to advocate for natural areas & Public \\
\hline Talking to neighbors about restoration of natural spaces & Public \\
\hline
\end{tabular}

Table 3: Attitude questions, with responses given on a 5-point Likert scale and associated conceptual constructs for each of the following statements.

\begin{tabular}{|l|l|}
\hline $\begin{array}{l}\text { Rate the degree to which you agree or disagree with the } \\
\text { following statements: }\end{array}$ & Attitude Constructs \\
\hline I feel a connection to this site & Place-based attachment \\
\hline I do this work mostly because I like socializing & Social/Community \\
\hline I like to be a part of community efforts & Social/Community \\
\hline I would be interested in moving into a volunteer leadership role & Giving Back \\
\hline $\begin{array}{l}\text { I feel like my work here contributes to a solution to current } \\
\text { environmental problems }\end{array}$ & Giving Back \\
\hline I enjoy nature-based education & Education \\
\hline $\begin{array}{l}\text { I am/would be interested in attending presentations about } \\
\text { restoration ecology }\end{array}$ & Education \\
\hline I pay attention to environmental issues & Environment \\
\hline $\begin{array}{l}\text { I identify myself as someone who cares about/for the } \\
\text { environment }\end{array}$ & Environment \\
\hline I identify myself as an environmentalist & Environment \\
\hline
\end{tabular}

Other questions were asked regarding volunteer preferences on stewardship events, and included whether volunteers enjoy working alone or in groups, if they 
enjoy the time of day and week that events are held, and whether they received a clear message for the purpose of the volunteer event. This information was not used directly for our analysis, but will be reported to the PPR stewardship coordinators, so that they might better understand their volunteers' preferences, and be able to target events to suit these responses.

The surveys were coded using a standard non-parametric ranking for responses. This numerical data was entered into an Excel spreadsheet. For responses to yes or no behavioral questions, we coded no=0, and yes $=1$. For responses to our attitude questions with multiple options, they were ranked on a five-point Likert scale, from "completely disagree" to "completely agree" with the central option being "no opinion or neutral", as described on the survey questionnaire. The Likert scale assumes that distances between responses are equal, lending itself to assess positive and negative responses to questions equally. To code the open-ended survey question regarding the impact of volunteering in stewardship in a qualitative manner, the graduate students in the Dresner lab of Portland State University's Environmental Science and Management department used alphabetical codes to summarize the responses (Table 4). Coding options were decided by group consensus, and there were six possible codes, with some responses receiving multiple codes. After independently assigning codes to the open-ended responses, codes with majority agreement were determined for each response. Qualitative analysis was conducted for the open-ended question that we coded as a group. This coding was not used in any of the quantitative statistics described. 
Table 4: Qualitative coding options for the open-ended survey question assessing motivations to volunteer and the impact from volunteering.

\begin{tabular}{|l|l|}
\hline Code & Description \\
\hline E & $\begin{array}{l}\text { Environmental benefits (making things green, being in nature, restoration, } \\
\text { invasive species removal, etc.) }\end{array}$ \\
\hline S & $\begin{array}{l}\text { Social (meeting people, seeing people I like, being with community } \\
\text { members, sense of belonging, etc.) }\end{array}$ \\
\hline P & $\begin{array}{l}\text { Personal benefit (weight loss, well-being, personal accomplishment, stress } \\
\text { relief, etc.) }\end{array}$ \\
\hline A & $\begin{array}{l}\text { Awareness (learned more about environment, knowledge of personal } \\
\text { impacts, education, etc.) }\end{array}$ \\
\hline G & Giving back (philanthropy, making a difference, seeing impact, etc.) \\
\hline L & $\begin{array}{l}\text { Location-specific (investment in this park or outdoor space, place-based, } \\
\text { etc.) }\end{array}$ \\
\hline
\end{tabular}

\section{Data Analysis}

We calculated differences in frequency of participation of volunteers, breaking frequency into three levels corresponding to the three-tiered typology of environmental literacy (Marcinkowski 2004). The "empowerment" level was interpreted to be for very frequent (more than 10 times per year; $n=43$ ) volunteers, the "ownership" level, volunteers participated frequently (3-10 times per year; $\mathrm{n}=46$ ) and "entry" level volunteers were those who participated once or occasionally ( 1 or 2 times per year; $\mathrm{n}=42$ ). We explored other metrics to split our data in analysis, such as differences in responses based on stewardship event location or seasonality, but there were no significant differences. Based on this, we decided to only present analysis based on the environmental literacy groups presented in our conceptual model. All statistical analysis was conducted using the program "R", version 2012. All summary statistics were generated using Microsoft Excel functions. Graphics were produced using Excel or "R". 
Our first time volunteers answered seven different attitude questions than the other volunteers. This was designed to reduce the number of reflective questions asked to those who did not have past experience volunteering in stewardship programs. However, all volunteers were asked the same behavioral questions. In order to include our first time volunteer attitudes in our data analysis, we found parallels between the questions, and assumed that first time volunteers would respond similarly to the attitude questions asked to more frequent volunteers. This method of response replacement, referred to as imputation, is used in these circumstances (Groves et al. 2004). Response replacements were agreed upon by the Dresner lab group for four out of seven first time attitude questions (Table 5).

Table 5: Response replacements to include first time volunteer attitudes in our data analysis, by imputing those responses for frequent volunteer attitude questions.

\begin{tabular}{|l|l|}
\hline First time volunteer question & Frequent volunteer question \\
\hline $\begin{array}{l}\text { I chose to volunteer at this location } \\
\text { specifically because of the location }\end{array}$ & I feel a connection to this site \\
\hline $\begin{array}{l}\text { I engage in environmentally-friendly } \\
\text { behaviors }\end{array}$ & $\begin{array}{l}\text { I identify myself as someone who cares } \\
\text { about/for the environment }\end{array}$ \\
\hline $\begin{array}{l}\text { I feel excited about giving back to the } \\
\text { community through volunteering }\end{array}$ & I like to be a part of community efforts \\
\hline I enjoy learning about the natural world & I enjoy nature-based education \\
\hline
\end{tabular}

A principal components analysis was conducted in order to understand the overall variation in the survey responses. This analysis was conducted without breaking the data into environmental literacy groupings. The questions selected for this analysis were the frequency of volunteering, and the five environmental attitude questions that had the most variability in their responses. These were specifically selected because there was the most variability found, as they likely hold more 
explanatory power in comparison to behavioral questions, which only had two response options.

A generalized linear model (GLM) was created examining how frequency of participation in stewardship might impact the motivation of participants. For this analysis, the data was split into the three environmental literacy groups based on volunteer frequency. Predictive values were determined for volunteer attitudes and behaviors within the three groups. This model was conducted using a backward stepwise GLM, by first creating a full model, and reducing the predictive variables based on their level of significance. Non-significant factors were dropped until the final reduced model was found. An additional model was generated in order to predict the frequency of volunteering, which used the full dataset. The same backward stepwise methodology was used. 


\section{Results}

Overall, our volunteers showed a strong dedication to volunteering in stewardship, had a variety of motivations to participate, and differing attitudes and behaviors related to environmental sustainability. Most volunteers (67\%) indicated that they received a communication from PPR indicating that there was physical need for volunteers to complete the restoration activities at hand, and many (61\%) also understood there was an immediate environmental need that they then responded to by participating in stewardship.

\section{All Volunteers}

Volunteers responded positively to many of our questions regarding participation in sustainable behaviors (Table 2). These were divided into private and public environmental behaviors. One question, regarding a negative environmental behavior of whether volunteers use pesticide in their yards, received an overwhelming amount of negative answers. Only $8 \%$ of volunteers reported using pesticides, but all other private behaviors emphasizing environmentally sustainable actions received around $80 \%$ agreement or higher (Figure 2). Our two questions regarding public environmental behaviors had lower overall positive responses, with about $50 \%$ of volunteers saying they talk to their neighbors about restoration and $47 \%$ saying they contact local officials to advocate for natural areas. These two questions yielded interesting differences to distinguish responses based on volunteer frequency. 


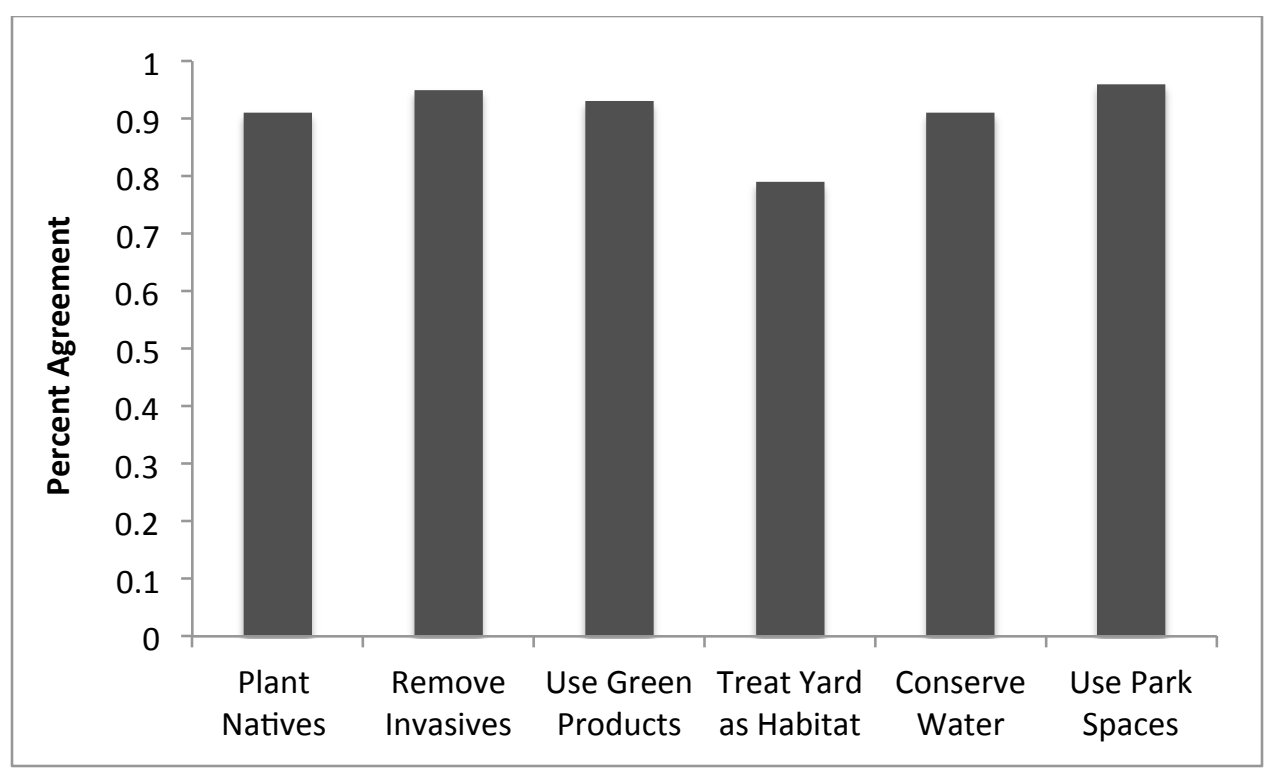

Figure 2: Responses from all volunteers to behavioral questions with about $80 \%$ agreement or higher

Responses to attitude questions (Table 3) had more variety, likely due to more response options. Half of our attitude questions received an overwhelming amount of positive responses $(80 \%$ or more of all respondents indicated somewhat (4) or completely (5) agree). These questions with high agreement were: caring about the environment, liking to be part of community efforts, enjoying nature-based education, paying attention to environmental issues, and feeling like their work contributes to solutions to environmental problems. The remaining attitude questions had more variety within the responses, as depicted in Figure 3 below.

These attitude questions with the most variation were used for our principal component analysis, to determine if our volunteers may be grouped based on their responses to these questions and their frequency of volunteering. These attitude questions with the most variation represent our conceptual framework, as each question represents responses based on a different aspect of natural area 
stewardship. Feeling a connection to the site is a question about the place-based relationship to volunteering, enjoyment of socializing represents the personal benefits created by a social network of volunteers, interest in a leadership role displays a willingness for a higher degree of participation as a stewardship volunteer which we defined as "giving back" through volunteering, interest in restoration ecology indicated a desire for education in stewardship events, and finally an environmentalist identity shows a strong concern for the environment displayed through volunteering in stewardship.

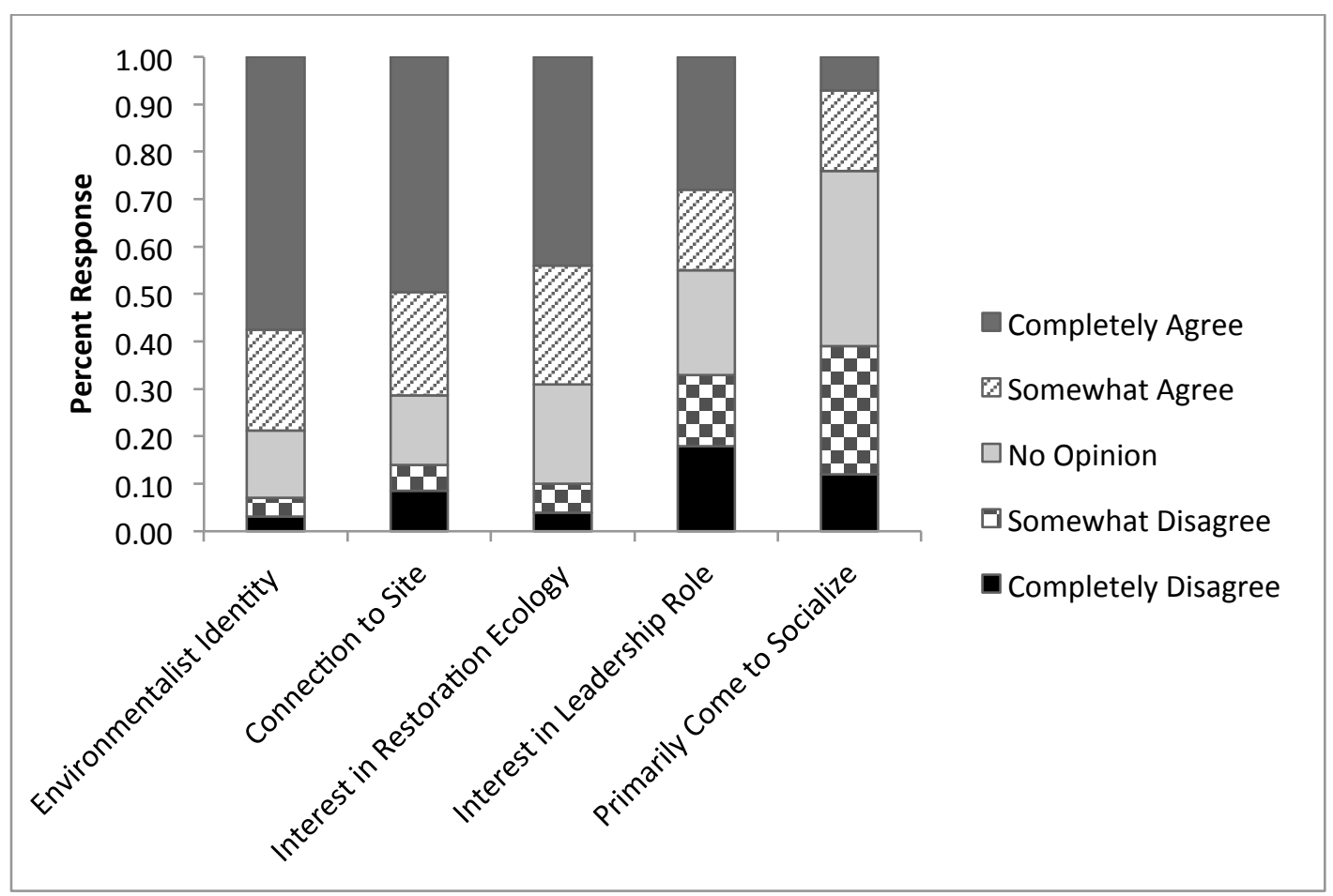

Figure 3: Responses from all volunteers to attitude questions with the highest level of variation within responses.

\section{Motivations to participate}

Motivations to participate as a volunteer were determined in two ways: a forced choice question, "Which is the most compelling reason you volunteered here today," 
and an open-ended question, "What impact has working on environmental restoration had on you?" For the forced choice question, more volunteers (43\%) indicated helping the environment was the most compelling reason, compared to other options. This was the most frequent answer overall, regardless of volunteer frequency. The next most frequent responses were for community improvement (23.5\%), and enjoyment of working outside (12.5\%), as shown in Figure 4.

However, when responses from the open-ended question, where volunteers were asked to indicate the impact stewardship work had on them, were qualitatively compared, the array of responses was different. The answer most frequently given for volunteers was increased awareness (48\%), followed by personal benefits (45\%) such as stress relief or other measures of well being, and then environmental benefits (27\%). Full results from this qualitative coding can be found in Table 6 . Percentages add up to over $100 \%$ as a result of single responses having multiple codes. 


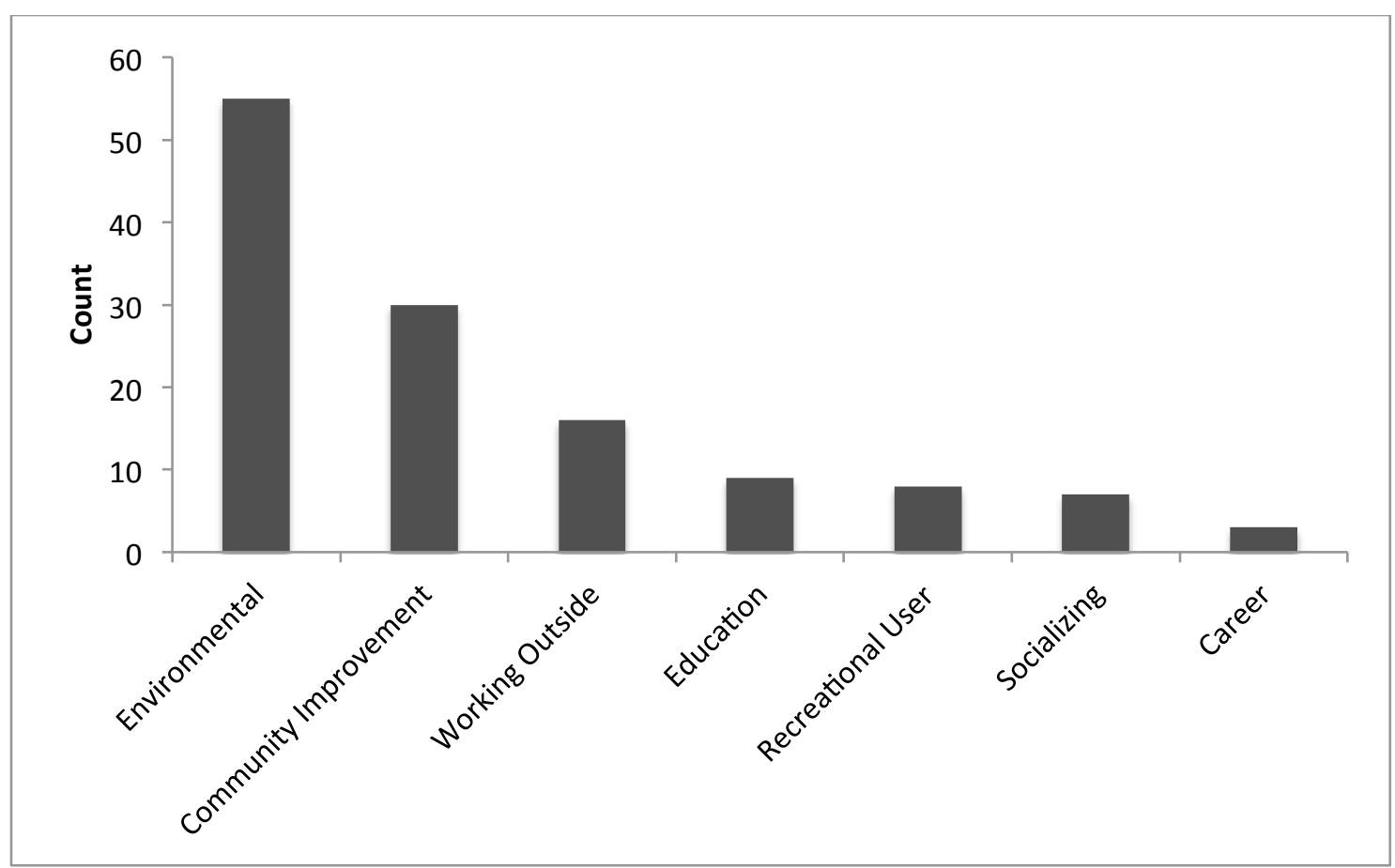

Figure 4: Volunteer responses to the forced-choice question, "Which is the most compelling reason you volunteered here today?"

Table 6: Volunteer responses to the open-ended question, "What impact has working on environmental restoration had on you?" Responses are categorized based on our coding protocol.

\begin{tabular}{|l|l|}
\hline Code & Percentage of Respondents \\
\hline Awareness & $48 \%$ \\
\hline Personal Benefit & $45 \%$ \\
\hline Environmental Benefit & $27 \%$ \\
\hline Giving Back & $26 \%$ \\
\hline Social Outcomes & $20 \%$ \\
\hline Location Specific & $15 \%$ \\
\hline
\end{tabular}

Approximately half of our open-ended responses were given multiple codes; therefore we sought to focus on these answers that cited multiple benefits of volunteering in stewardship. The primary categories of overlap in responses were 
seen as environmental benefits and awareness, personal benefits and awareness, social outcomes and personal benefits, and finally personal benefits and giving back (Table 7). This high level of overlap of personal benefits and other outcomes indicates that while our volunteers do enjoy individual benefits, those outcomes that are primarily personal reasons to volunteer are not the primary motivation to return. Stewardship volunteers cannot be reduced to singular categories of motivation, and we see that there are complex relationships between motivations to participate and beneficial outcomes of volunteering.

Table 7: Overlapping benefits derived from volunteer stewardship, as given in responses to our open-ended question. Percentages are based on total number of respondents, regardless of whether they received multiple codes.

\begin{tabular}{|l|l|l|l|l|}
\hline Codes & $\begin{array}{l}\text { Personal } \\
\text { Benefits \& } \\
\text { Giving } \\
\text { Back }\end{array}$ & $\begin{array}{l}\text { Personal } \\
\text { Benefits \& } \\
\text { Awareness }\end{array}$ & $\begin{array}{l}\text { Environmental } \\
\text { Benefits \& } \\
\text { Awareness }\end{array}$ & $\begin{array}{l}\text { Personal } \\
\text { Benefits \& } \\
\text { Social } \\
\text { Outcomes }\end{array}$ \\
\hline $\begin{array}{l}\text { Percent of } \\
\text { Respondents }\end{array}$ & $12 \%$ & $11 \%$ & $11 \%$ & $10 \%$ \\
\hline
\end{tabular}

\section{Environmental Literacy Groups}

Our volunteers were almost evenly split between our three levels of volunteer frequency. We found a few distinct patterns of volunteer attitudes and behaviors based on frequency of volunteering. As volunteers participate more frequently, they are also more likely to participate in public environmental behaviors, such as talking to neighbors about restoration and advocating for natural areas. They are also more likely to treat their own yards as wildlife habitat, which displays a concern for public natural areas, as well as general ecosystem connectivity and health. More frequent volunteers were also more likely to agree or strongly agree that they care about or 
for the environment, and that they pay attention to environmental issues. Finally, those who volunteer with high frequency also feel more connected to their volunteer site, which displays a place-based connection that results from stewardship.

Some attitudes did not show strong patterns across our environmental literacy groupings, because volunteers showed strong levels of agreement regardless of volunteer frequency. Many volunteers agreed that they enjoy nature-based education, though fewer responded that they would attend presentations on restoration ecology. We found that most volunteers responded that they enjoy being part of community efforts, which shows a strong attitude of social belonging and the personal benefits that can result from participation. Additionally, many volunteers somewhat or completely agreed that they feel their work contributes to a solution to environmental problems, showing a strong realization of the impact of their stewardship efforts.

These same relationships did not occur when examining our data through other potential metrics for splitting our survey responses into groups. For example, attempts to find relationships between volunteer responses and season or location of volunteer events (i.e.: on the Eastside or Westside of Portland) yielded no significant results. Because we found no differences in grouping responses using these methods, the results are not reported further. However, implications of the even distribution, independent of location or season is discussed below. 


\section{Assessing Variation of Survey Responses}

Our principal component analysis was conducted using information regarding the frequency of volunteering and the five attitude questions with the most variation in responses (Figure 3). This would result in an output of six different principal components, due to the input of six variables, but we found that the majority of the variation within our data can be explained by the first two principal components. This analysis reveals that $35.5 \%$ of the total variation in our data can be explained by our first principal component, and an additional $21.3 \%$ of the variation in our data can be explained by our second principal component. The first principal component is defined primarily by: frequency of volunteering, having interest in becoming a volunteer leader, and having interest in learning about restoration ecology (Table 8). We observe that interest in becoming a volunteer leader contributes the most explanation to this principal component, which defines a desire for larger commitment as a volunteer, and possibly also for a desire for more training to become a stewardship event leader. Our second principal component can be described by: frequency of volunteering, interest in learning about restoration ecology, and identifying as an environmentalist (Table 8). Volunteer frequency is the most important factor in this principal component, suggesting that there is some inherent change in responses to survey questions overall as volunteers participate more frequently. While there is overlap in explanatory value by some questions, the principal components are independent. 
Results from our principal component analysis suggest that there is no strong grouping of survey responses based only on volunteers' responses to our most variable attitudinal questions (Figure 3) and their frequency of volunteering. Volunteers at all frequencies of participation had high level of agreement in many responses. This could mean that our principal component outputs show a gradual increase in explanatory value with each added component, rather than a high degree of initial explanation that quickly drops with additional variables.

This analysis also shows that our data does not cluster according to frequency of volunteering, when examining attitude questions and the frequency of volunteering only. However, we can see that most of the variation in our survey responses overall results from responses to volunteers' interest in becoming a leader and frequency of volunteering increase. When assigned groups " $\mathrm{A}$ " for empowerment level, "B" for ownership level, and "C" for entry level, we cannot distinguish any ordered grouping according to our principal component plot (Figure 5). Based on this, we can tell that many volunteers answered attitude questions in a similar manner, though responses did seem to fall along gradient lines based on interest in becoming a volunteer leader and frequency of volunteering. Also, we had fewer responses to some attitude questions from first time volunteers, since they had not participated in stewardship previously. This makes our overall number of data points for group " $\mathrm{C}$ " lower than "A" and "B", which might impact the results from our principle component analysis. The eigenvectors associated with the principal 
components can be found in Table 8 below, and are displayed as vectors on our biplot (Figure 6).

Table 8: The strongest eigenvectors in Principal Component 1 and Principal Component 2. Eigenvectors were only included if they were greater than 0.3 .

\begin{tabular}{|l|l|l|}
\hline & PC 1 & PC 2 \\
\hline Interest in becoming a volunteer leader & -0.716 & \\
\hline Frequency of volunteering & -0.436 & 0.783 \\
\hline $\begin{array}{l}\text { Interest in learning about restoration } \\
\text { ecology }\end{array}$ & -0.364 & -0.406 \\
\hline Identifying as an environmentalist & & -0.335 \\
\hline
\end{tabular}

This lack of complete clustering based on volunteer frequency might indicate that most of the differentiation between groups comes from responses to questions about sustainable behaviors or demographics. This provides valuable insight that while we might find some distinct patterns in the three levels of environmental literacy that correspond with volunteer frequency, they follow a steady gradient, rather than having distinct edges between groups. While our results from the principal component analysis show a gradient of responses, we chose to utilize the three-tiered environmental literacy scale to examine our survey responses further. We sought to determine if there was fit with this conceptual model since this is a novel approach to analyzing stewardship volunteer survey responses, and we feel that the literacy gained from participation make this form of volunteering a unique activity. We also reasoned that the environmental literacy scale itself was a gradient, since individuals do not neatly fit into single categories over time. 


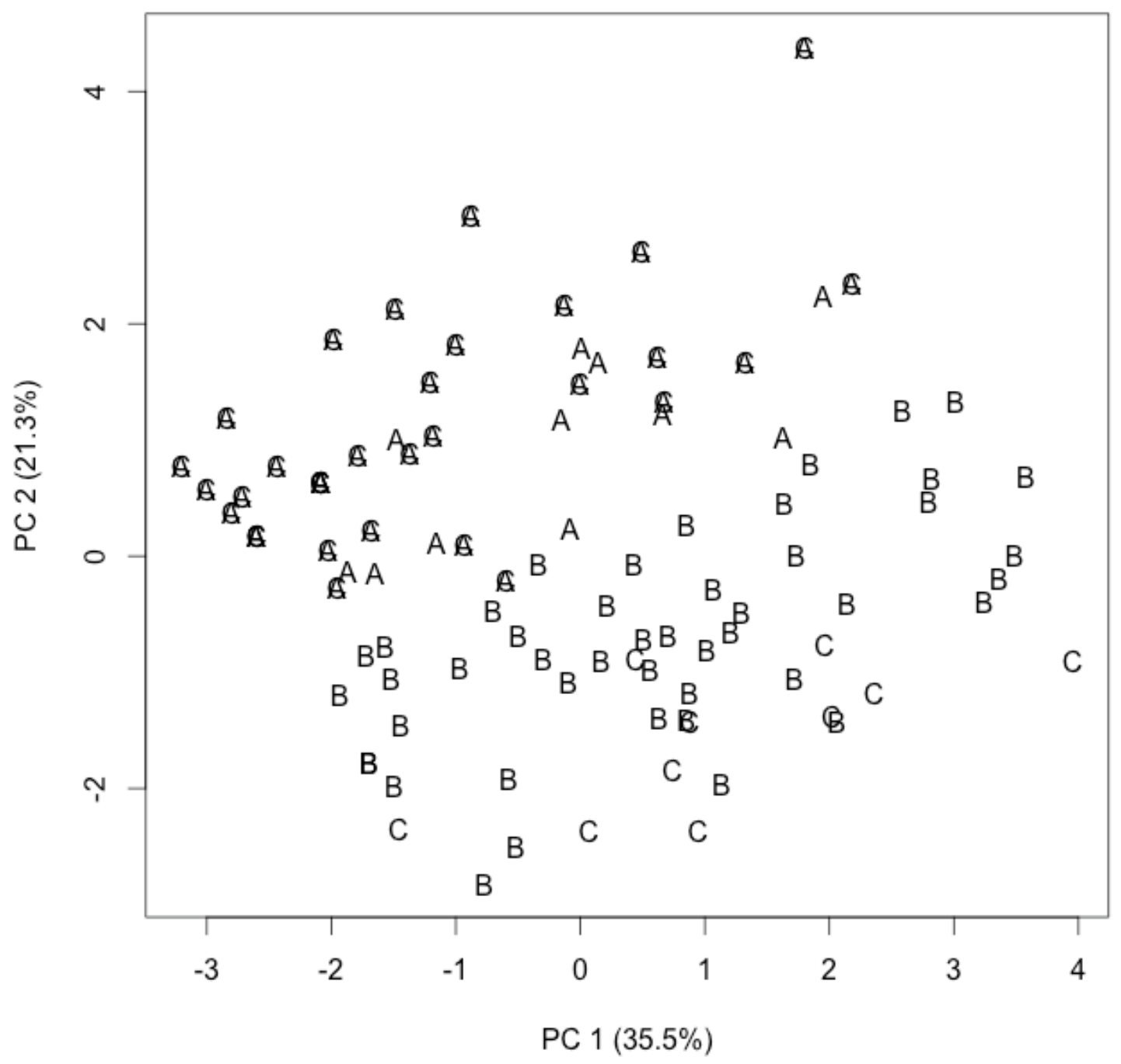

Figure 5: A plot depicting our two principal components with the highest degree of explanatory power. Survey responses are coded with labels "A" for entry level, "B" for ownership level, or "C" for empowerment level, according to environmental literacy groups. 


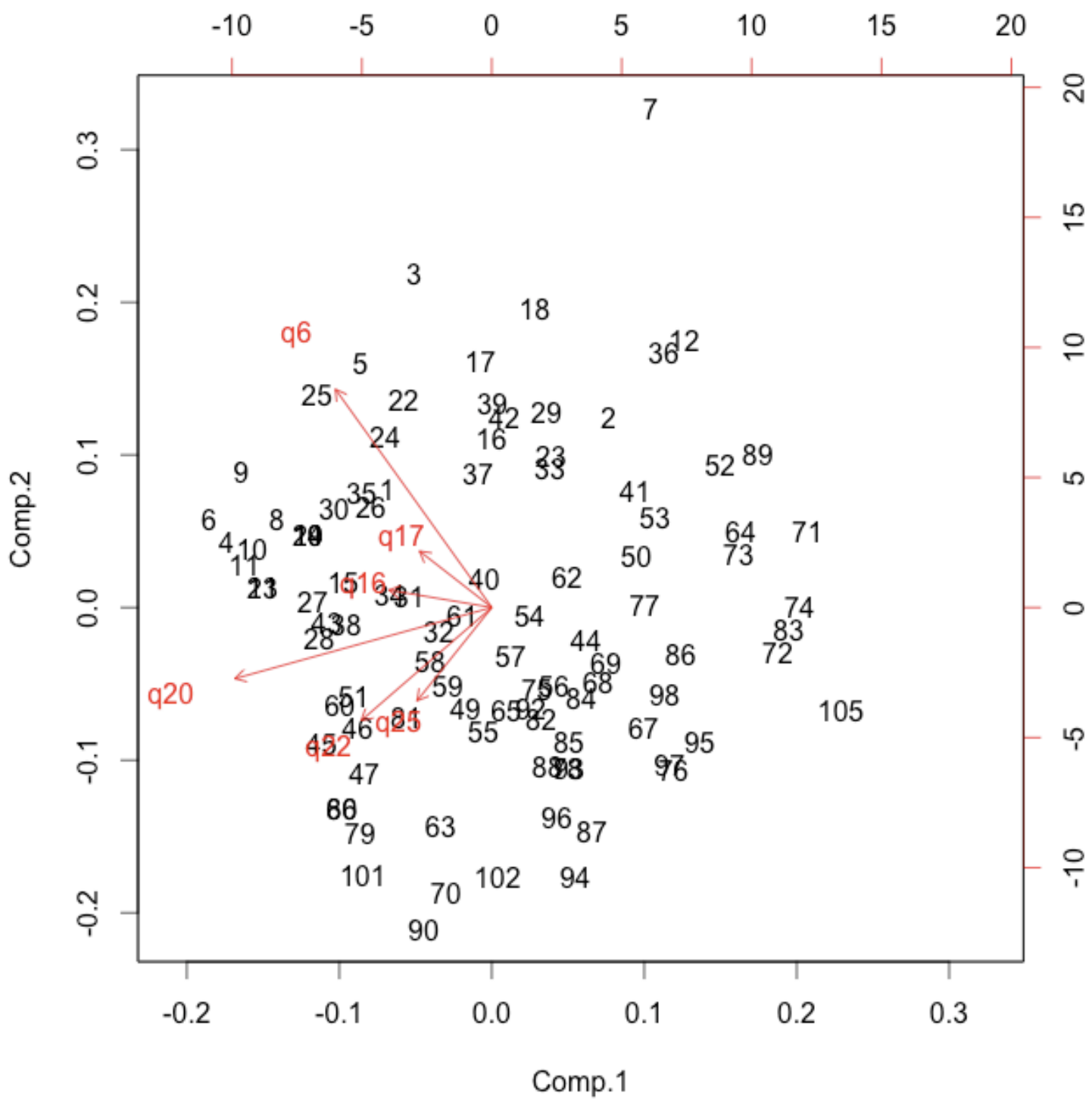

Figure 6: Biplot results for our principal component analysis, displaying our first two principal components, as well as the primary eigenvectors explaining this variance in our data. We can visualize the explanatory power, especially of interest in becoming a volunteer leader (vector q20) in explaining PC1 and frequency of volunteering (vector q6) in PC2. Each numbered data point represents a single survey responder. Question numbers can be found in Appendix B.

We see that the variation in responses to these six questions is not enough on its own to explain the overall grouping found in our volunteer responses. Since these 
five attitude questions do not fully capture the variety of responses, we must further examine the relationships between volunteer attitudes and behaviors.

\section{Frequency of Volunteering}

The results of the generalized linear model (GLM) performed to test which factors were best to predict the frequency of volunteering yielded the attitude of "I feel a connection to this site" $(\mathrm{p}<0.001)$ and the public environmental behavior "I contact local elected officials to advocate for natural areas" ( $\mathrm{p}<0.001)$. Other GLM tests were conducted to find predictive values of attitudes and behaviors within each of the three environmental literacy categories. The most meaningful results that represent the three levels of environmental literacy can be found in Table 9 below. These results correspond with our proposed scale of environmental literacy constructs (Table 1), though we were surprised to see public pro-environmental behaviors at the entry level.

Table 9: GLM outputs of behavioral predictors of attitude responses that are indicative of the three levels of environmental literacy and volunteer frequency.

\begin{tabular}{|l|l|l|l|}
\hline $\begin{array}{l}\text { Participation } \\
\text { Level }\end{array}$ & Attitude Response & Behavior Predictor & $\begin{array}{l}\text { Significance } \\
\text { (p-value) }\end{array}$ \\
\hline Entry & $\begin{array}{l}\text { I like to be a part of } \\
\text { community efforts }\end{array}$ & $\begin{array}{l}\text { I talk to neighbors } \\
\text { about restoration }\end{array}$ & 0.029 \\
\hline Ownership & $\begin{array}{l}\text { I care about the } \\
\text { environment }\end{array}$ & $\begin{array}{l}\text { I treat my backyard } \\
\text { as wildlife habitat }\end{array}$ & 0.035 \\
\hline Empowerment & $\begin{array}{l}\text { Interested in working as } \\
\text { volunteer leader }\end{array}$ & $\begin{array}{l}\text { I advocate for natural } \\
\text { areas }\end{array}$ & 0.016 \\
\hline
\end{tabular}

For entry level volunteers, the behavior of "I plant natives in my own yard" was predictive of caring about the environment $(\mathrm{p}=0.0003)$ and enjoying nature based 
education ( $\mathrm{p}=0.0113$ ). Additionally, caring about the environment was predictive of entry level volunteers who were likely to talk to neighbors about restoration of natural places ( $\mathrm{p}=0.0214$; Figure 7).

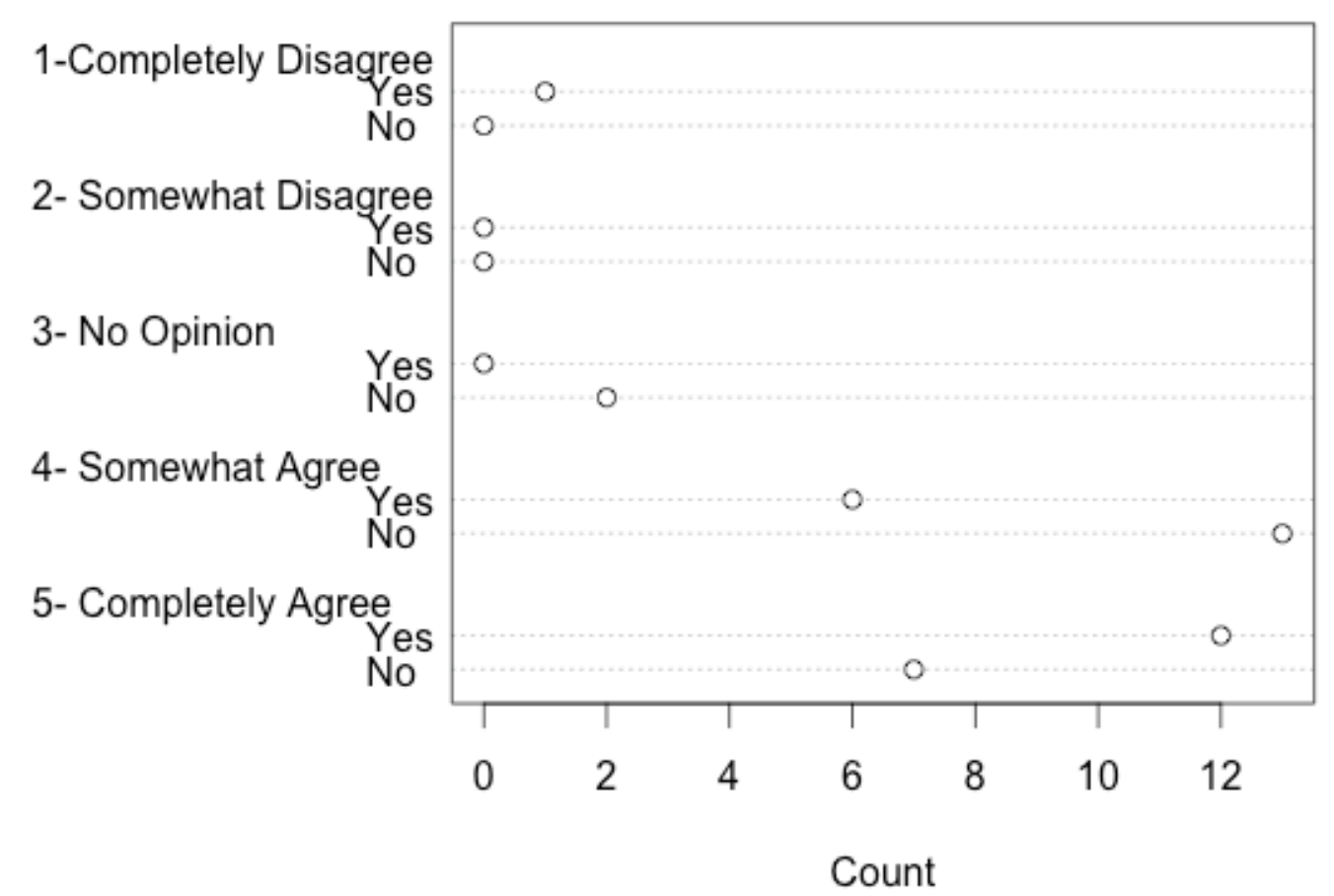

Figure 7: Responses from entry level volunteers to the attitude "I care about the environment" and behavior "I talk to neighbors about restoration of natural places".

Ownership level volunteers who responded positively to the behavior of treating their yard as wildlife habitat also identify as caring about the environment $(p=0.0346$; Figure 8). Additionally, those ownership level volunteers who would engage in the public environmental behavior of contacting local elected officials to advocate for natural areas responded positively to the statement "I feel a connection to this site" ( $\mathrm{p}=0.034 ;$ Figure 9). 


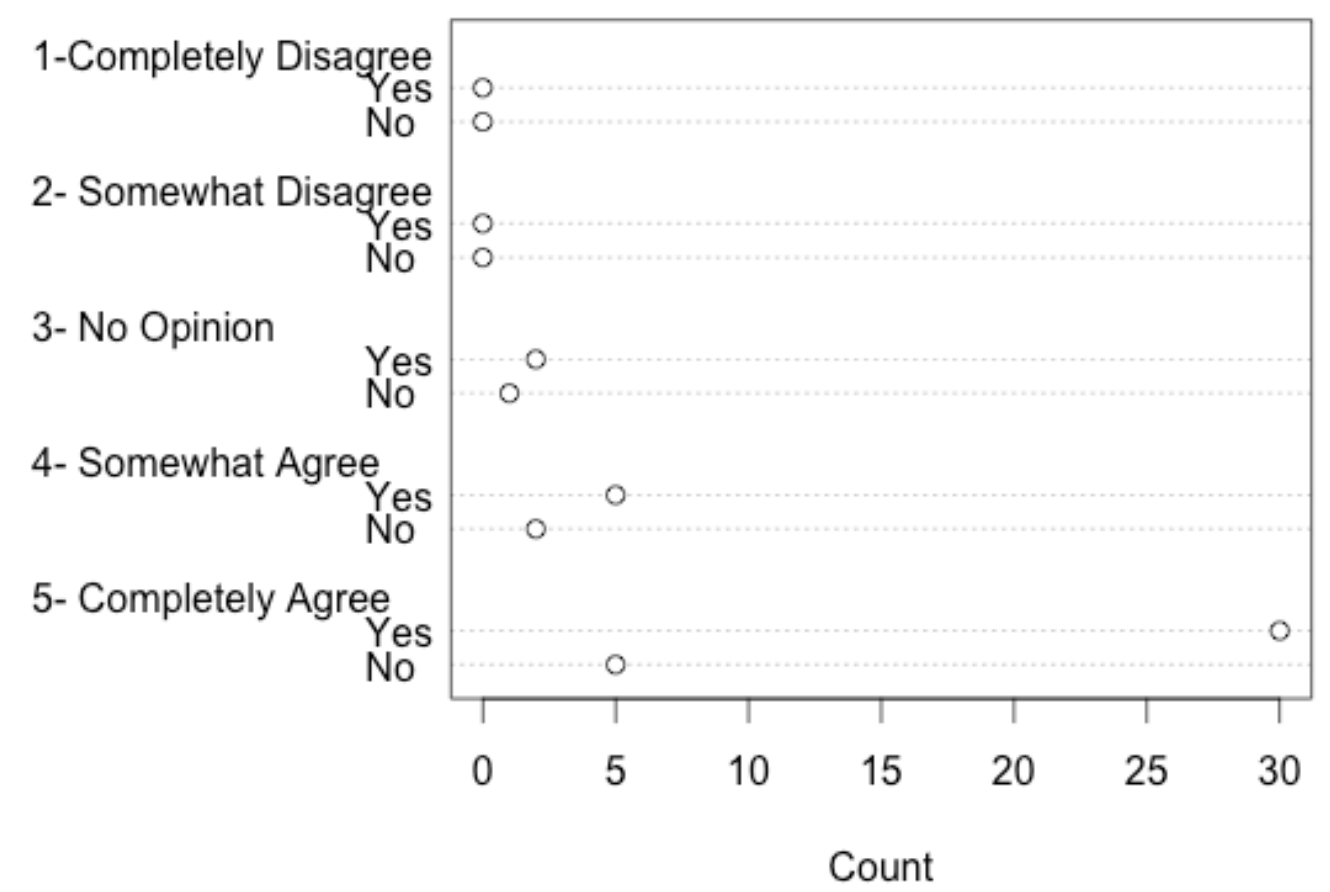

Figure 8: Responses from ownership level volunteers to the attitude "I care about or for the environment" and behavior "I treat my yard as wildlife habitat".

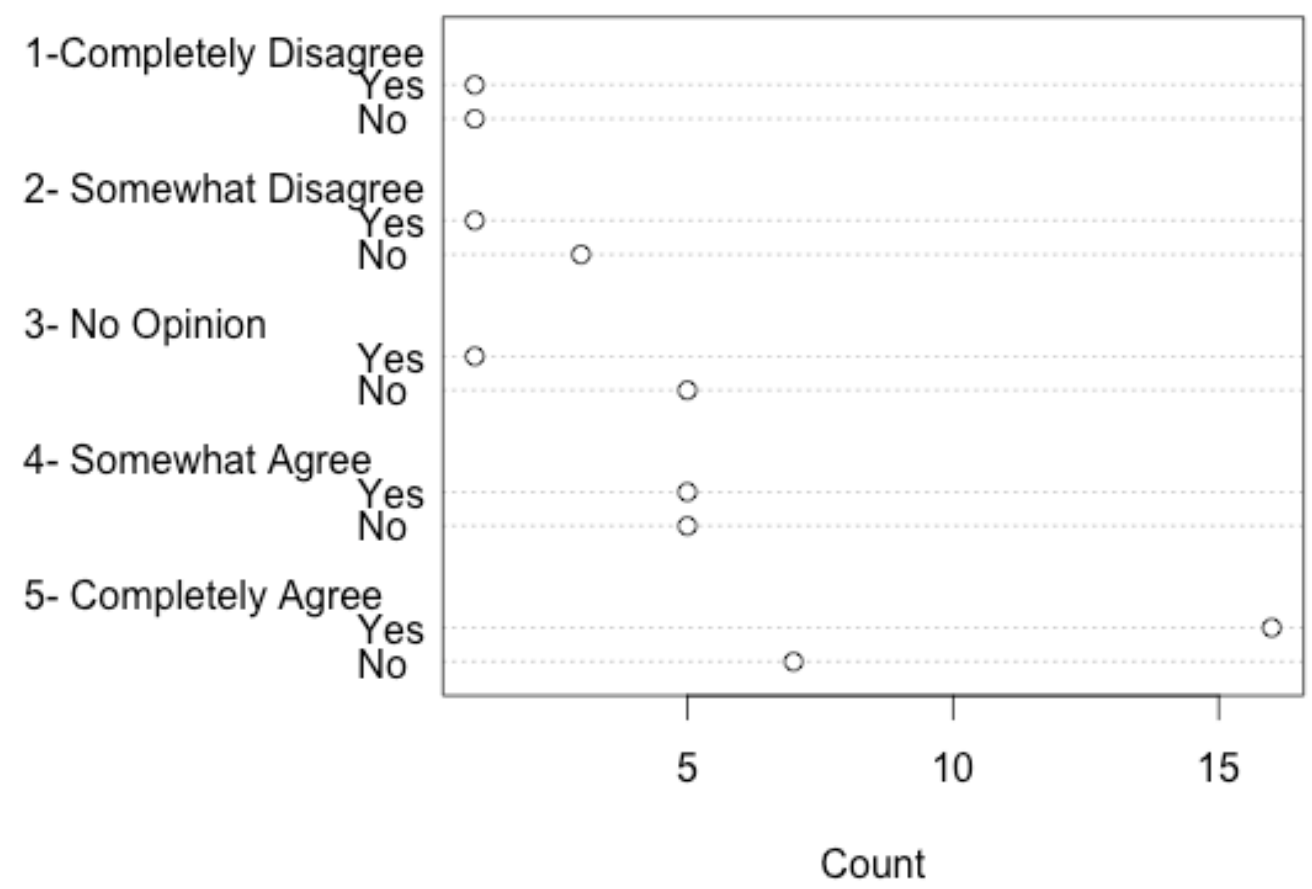

Figure 9: Ownership level volunteer responses to the attitude "I feel a connection to this site" and behavior "I contact local elected officials to advocate for natural areas". 
Empowerment level volunteers had a wide variety of responses with predictive value. For example, feeling a connection to the park site was predicted by talking to neighbors about restoration ( $\mathrm{p}<0.001$; Figure 10) and using natural park spaces in their free time $(\mathrm{p}=0.0002)$. Those who identify as someone who cares about the environment would contact local elected officials to advocate for natural areas $(\mathrm{p}=0.0264)$. Those who were interested in becoming a volunteer leader, in a role such as leading nature walks or teaching plant identification, were also likely to advocate for natural areas ( $\mathrm{p}=0.0162$; Figure 11). Finally, those empowerment level volunteers who felt like their work contributed to a solution to environmental problems responded positively to talking to neighbors about restoration of natural spaces $(\mathrm{p}=0.006$; Figure 12) and using park spaces in their free time $(\mathrm{p}=0.0317)$.

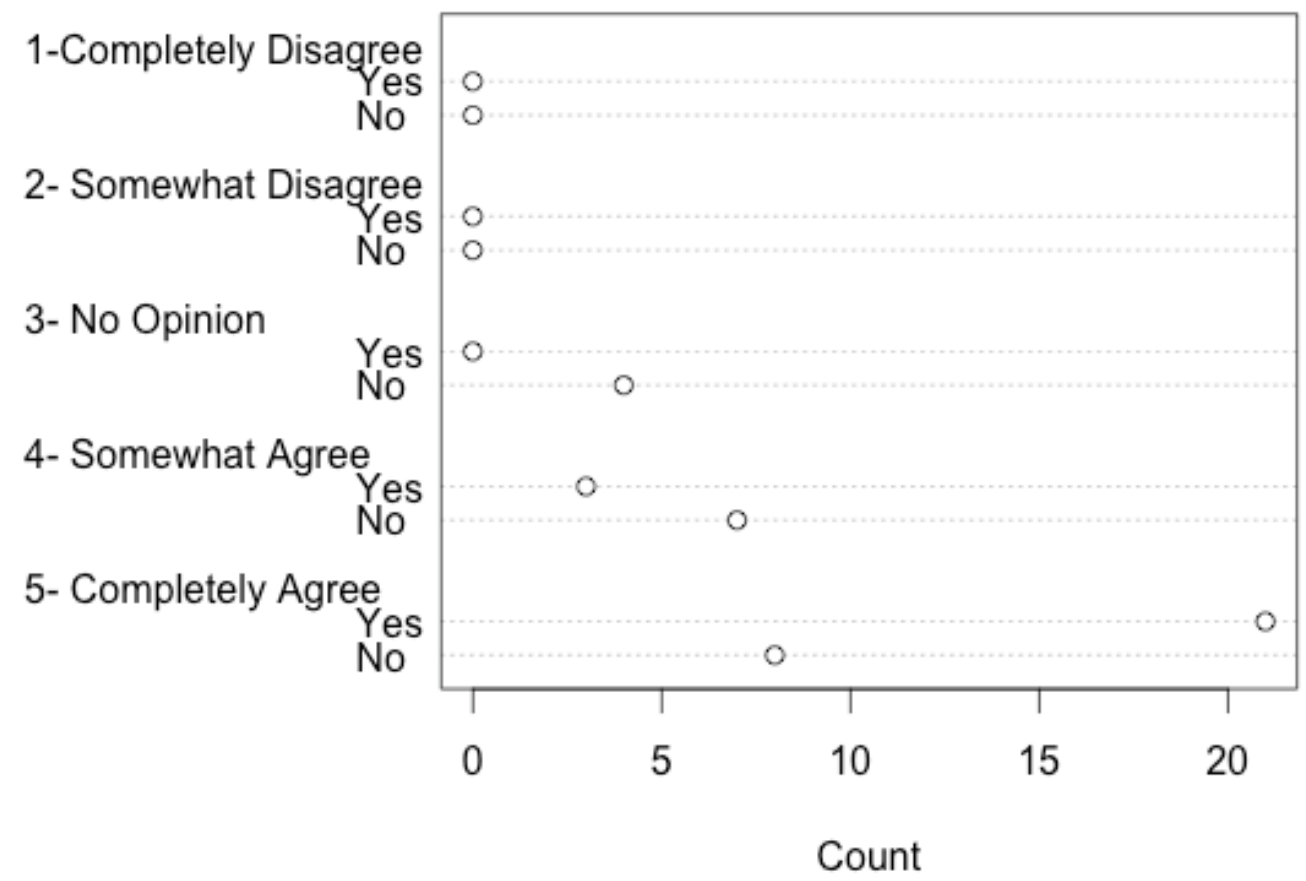

Figure 10: Empowerment level volunteer responses to the attitude "I feel a connection to this site" and behavior "I talk to neighbors about restoration of natural areas". 


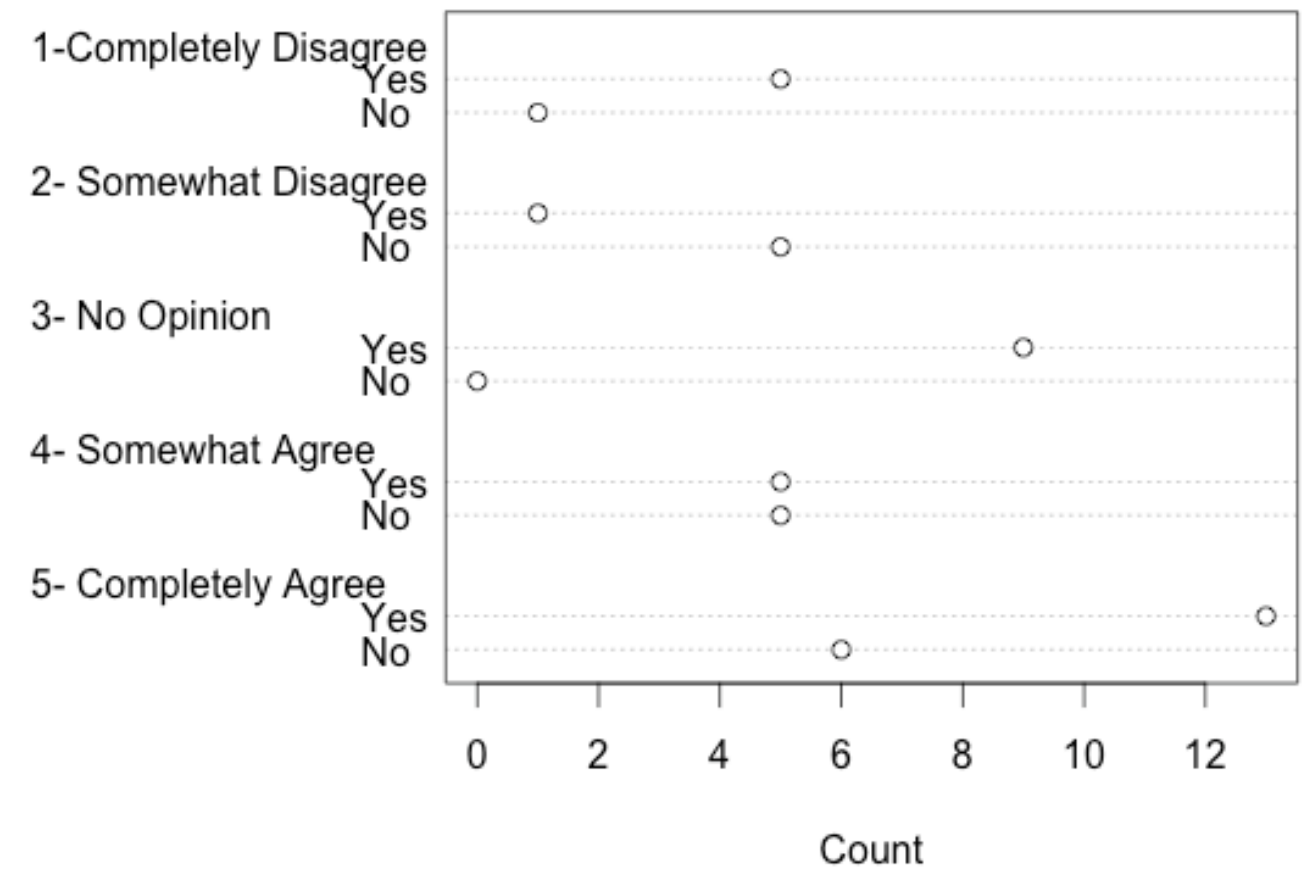

Figure 11: Responses from empowerment level volunteers to the attitude "I am interested in becoming a volunteer leader" and behavior "I contact local elected officials to advocate for natural areas".

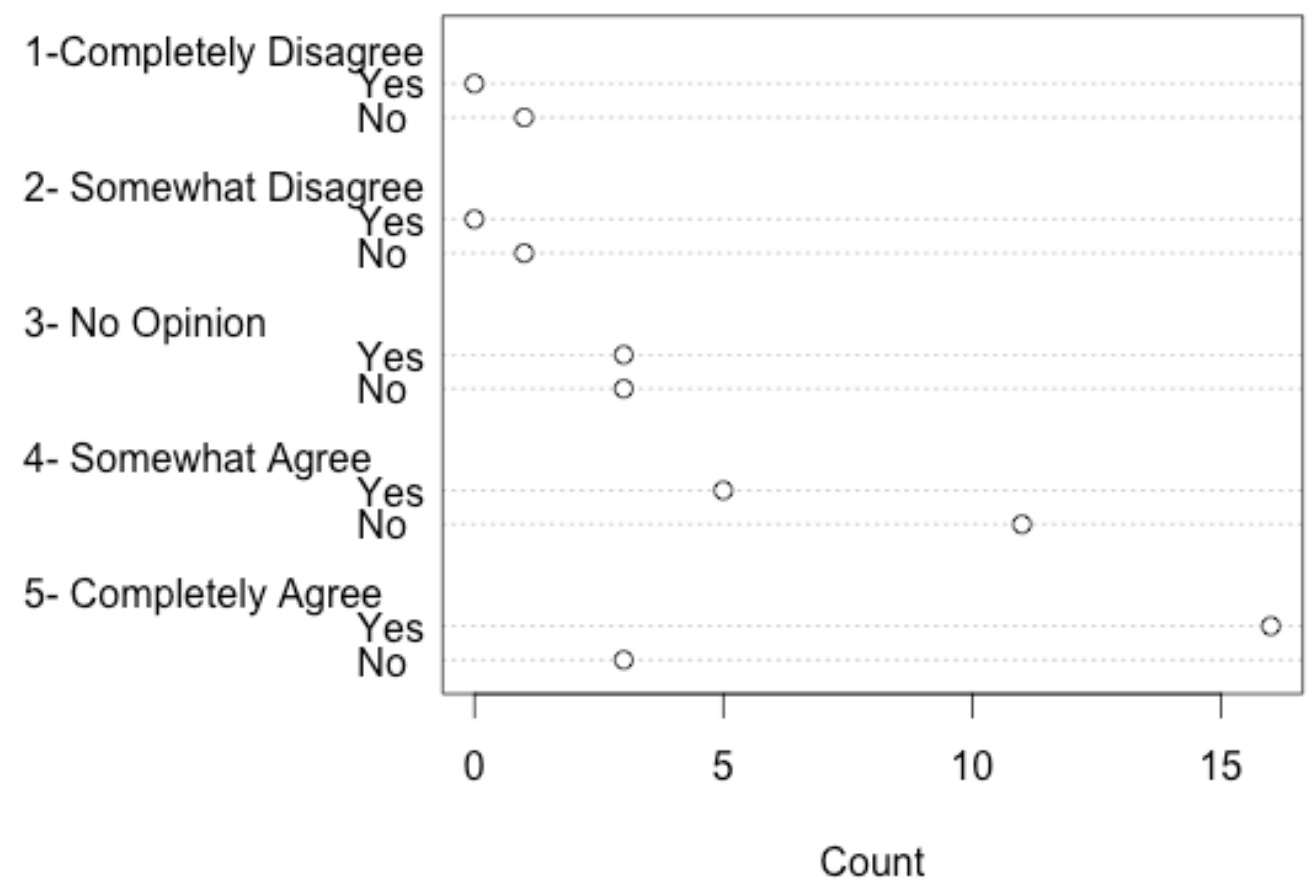

Figure 12: Empowerment level volunteers responses to the attitude "I feel like my work here contributes to a solution to current environmental problems" and behavior "I talk to my neighbors about restoration of natural areas". 


\section{Demographic Information}

Our total surveyed volunteer population was evenly split between males and females (49.6\% F, 50.4\% M), and the average volunteer was 41.5 years old. Most volunteers reported their ethnicity as "Caucasian" (85\%). A vast majority of volunteers had at least some college education (95\%), with many holding a graduate or professional degree (26\%). Most volunteers were employed at least part-time (59\%), and other frequent responses to employment status were retired (13\%) and student (11.5\%). The average household size was 2.3 persons, and most volunteers $(60 \%)$ had an annual household income of $\$ 60,000$ or below. Volunteers spent an average of about 20 minutes traveling to the event, and $75 \%$ used a personal vehicle as the primary mode of transportation to the event. The number of volunteers who reported driving includes those who carpooled.

The demographic makeup of volunteers did differ somewhat between the three levels of volunteer frequency. More empowerment-level volunteers held graduate or professional degrees than other levels. Entry-level volunteers were more likely to be students than volunteers at other levels, and were an average of almost 10 years younger than volunteers at higher frequency levels. Full comparisons can be found in Table 10 below. 
Table 10: Demographic information of respondents split based on the three levels of volunteer frequency.

\begin{tabular}{|c|c|c|c|}
\hline & Entry & Ownership & Empowerment \\
\hline Average Age & 34.81 & 42.35 & 47.05 \\
\hline Percent Males & $52.4 \%$ & $39.1 \%$ & $60.5 \%$ \\
\hline Percent Caucasian & $74 \%$ & $82.6 \%$ & $97.7 \%$ \\
\hline $\begin{array}{l}\text { Most Common } \\
\text { Education Level }\end{array}$ & Some College & College Degree & $\begin{array}{l}\text { Graduate or } \\
\text { Professional } \\
\text { Degree }\end{array}$ \\
\hline $\begin{array}{l}\text { Most Common } \\
\text { Household Income }\end{array}$ & $\begin{array}{l}\text { Under } \\
\$ 20,000\end{array}$ & Under $\$ 20,000$ & $\$ 40,000-\$ 60,000$ \\
\hline $\begin{array}{l}\text { Average Number of } \\
\text { People in } \\
\text { Household }\end{array}$ & 2.5 & 2.43 & 1.98 \\
\hline
\end{tabular}




\section{Discussion}

\section{Overall Findings}

Volunteers who participated in PPR stewardship events showed an overall high degree of concern for the environment, a strong sense of doing positive work for the community, and reported participating in many pro-environmental behaviors. From our study, we believe that Portland area volunteers have a strong sense of concern for the environment in general, which might extend beyond stewardship alone (Johnson 2004). Our volunteers also stated that they participate as volunteers for a wide variety of other organizations, which shows that many causes are worth dedicating their time to. The high level of agreement with many of our proenvironmental attitudes, such as caring about the environment and enjoying naturebased education, shows that our volunteers are engaged with the environmental purpose of stewardship. Additionally, around $80 \%$ or more of our volunteers reported participating in private pro-environmental behaviors.

We found that there were no significant differences in volunteer responses between events held at different locations around Portland or in different seasons. We feel that this shows a fairly even distribution of volunteers who are dedicated to their involvement in stewardship, regardless of where they live within the city or what natural area they choose to volunteer for. Additionally, the lack of pattern correlated to season might be due to two reasons. First, we could see a pattern that first time or frequent volunteers are not influenced to attend based on the season. Another explanation might be that many events we surveyed were held on days 
with poor weather, regardless of the season. This might capture a dedicated group of volunteers who come during times of harsh weather, which we believe might influence the number of empowerment level volunteers who were surveyed. This explanation might be supported if we surveyed further into the summer months of July and August, to determine if more entry or ownership level volunteers were present during stewardship events with pleasant weather. However, since we designed our study to only sample each PPR natural area once, we were unable to attend summer events.

\section{Environmental Literacy Constructs}

We sought to organize meaningful associations between the frequency of a volunteer's participation and their associated attitudes and behaviors within an environmental literacy scale (Marcinkowski 2004). Overall, we found a high degree of fit. This perspective of stewardship as an educational experience and applying the environmental literacy scale is a novel approach to analyzing volunteer survey responses. By utilizing the lens of environmental literacy, we are ascribing benefits derived by volunteers, since they exhibit more environmentally conscious attitudes and behaviors as volunteer frequency increases (Hungerford and Volk 1990).

At the entry level or beginning level of volunteering, we saw evidence of environmental sensitivity. Entry level volunteers indicated that they participate in private sustainable behaviors, and surprisingly some even participated in public 
pro-environmental behaviors. At the ownership level of volunteering, where volunteers participate more often over the year, we see that they are making a personal investment in helping to protect the environment. These ownership level volunteers show a high degree of care about the natural environment and participate in many private sustainable behaviors to support their concerns. These volunteers even begin to develop a connection to the stewardship site, indicating a place-based attachment (Ryan 2005). At the empowerment level, volunteers are more likely to participate in public environmental behaviors and want to work in volunteer leadership positions. We found that the most frequent volunteers also indicated they felt their work on the site contributes to solving environmental problems, which reinforces the "empowerment" title given to this level of environmental literacy.

We believe that as volunteer frequency increases, participants become increasingly environmentally literate, as indicated by their responses showing greater concern for the environmental purpose of the event. Those volunteers at the empowerment level of environmental literacy indicate that they do come to socialize and see the impact of their results over time. Based on these responses, we may assume that over time a community of stewards develops around individuals and the places they work. Through our empowerment level volunteer responses we see how volunteering is a behavior itself, which reinforces this stewardship ethic (Worrell and Appleby 2000). This reinforcement not only creates a stronger connection to the volunteer restoration site, but may also empower volunteers to become 
advocates within their community, create networks of volunteer stewards, and display their concern for the environment through their personal behaviors. These factors combine to show that knowledge increases with volunteer frequency, as participants feel that their work has an impact to solve environmental problems, which is a display of increased environmental literacy (Disinger and Roth 1992).

Our volunteers can also be compared demographically to the environmental literacy scale, and we found a high degree of demographic fit to this model (Marcinkowski 2004). As volunteer frequency increases, so does average age, household income, and education level. This increase in volunteer frequency is also negatively related to the number of people per household, which might indicate that as volunteers are older and are more educated, they are also less likely to have dependents, roommates, or other individuals in their home.

\section{Motivations to Participate}

While we did find that our stewardship volunteers indicated they cared deeply about the environment and were motivated to participate as a result of this care, we did find a difference between the primary motivation to volunteer and the impact of volunteering. This discrepancy between the primary motivation to volunteer and the personal impact of volunteering may be due to the differences found between a forced-choice and open-ended question. Further explanation may come from the fact that the questions were worded asking for different responses. Our volunteers 
might not have felt that the benefits derived from stewardship volunteering were directly linked to the motivations they felt to return as a volunteer. Additionally, our volunteers might come intending to fulfill some purpose, such as seeing beneficial restoration to the local environment, yet gain more in return, such as the multiple benefits we often saw reported. Since many volunteers reported paired benefits of participation, we can see that there may be a variety of factors that influence continued participation in stewardship volunteering that extend beyond responses to our forced-choice question on motivation to volunteer. The most commonly cited personal impact, increased awareness, included statements regarding learning more about the environment, increased knowledge of personal impacts to the environment, and other educational outcomes. These do not exclude an acknowledgement of environmental impacts; in fact, some responses that cited increased awareness also discussed the environmental benefits of stewardship, such as accomplishing restoration goals, being in nature, and making things "green".

Helping the environment was the stated highest motivation for doing stewardship work at all levels of volunteer frequency. This motivation is also inherently linked to the relations of pro-environmental attitudes and behaviors expressed by many of our volunteers (Ryan et al. 2001). Regardless of this being the primary reason to volunteer across all frequencies of volunteers, we still saw that attitude items, such as an environmentalist identity, positively increased with volunteer participation. Secondarily, many volunteers cited community improvement as their motivation to participate. These two combined reasons to volunteer, environmental benefits and 
community improvement, create an environmentally conscious community of stewardship volunteers (Shandas and Messer 2008). When we also look at these primary motivations in combination with increased awareness as a highly cited outcome of stewardship participation, we see signs of an ethic forming between motivations, attitudes, and positive benefits derived from stewardship participation.

\section{Attitude-Behavior Responses}

We discovered an association between attitude and behavior variables that defined a population of volunteers who cares considerably about the environment and engages in sustainable behaviors. This supports most of the existing research on attitudinal variables, which is that most members of environmental organizations expressed strong attitudes about the seriousness of environmental problems (Manzo and Weinstein 1987). We also found a high number of volunteers indicating they cared about the community and were also involved as volunteers in many other organizations. Social interaction appeared to be an important motivating force for continued involvement (Wolf et al. 2011). This feeling of engagement with the local community in a social network appears to be second in importance to environmental issues based on our volunteer population, but the ability to socialize while volunteering is important to those who participate in stewardship (Manzo and Weinstein 1987). 
The relationship between attitude responses, motivations to attend stewardship events, and the frequency of volunteer participation may provide insight into the process by which volunteers become more involved over time. Many entry level volunteers indicated that they do enjoy the social aspects of stewardship events, and appreciate other personal benefits of volunteering. They may first become engaged in natural area stewardship due to a wish to meet like-minded people who also care about service, or to fulfill a personal desire to work outside or give back to their local community. Those volunteers attending events at the ownership level, three to ten times per year, indicated they did not come primarily to socialize. As a result of this difference, we may assume that something changes for volunteers as they become more involved in stewardship. These benefits that result from participation in volunteer stewardship then feed back as motivations to return (Grese et al. 2000). This feedback, when deemed positive by participants, can lead to increased frequency of volunteering.

Volunteer restoration activities may be highly important in developing an attachment to one's volunteer site. Our stewardship volunteers who indicated a strong connection to the natural area in which they volunteer exhibited other behaviors indicating a place-based attachment, such as using natural park spaces in their free time. The most frequent participants also felt the most highly connected to the site, which might be a result of their continued efforts over time. When volunteers can personally observe transformation from their actions over time, such as removing invasive species from an ecosystem, their place-based connection and 
motivation to return as a volunteer can increase (Ryan 2005). An increased connection to nature that results from continued environmental stewardship might also influence the desire to make decisions that are beneficial to the environment, indicating volunteers feel that their work has a large positive impact (Kaplan 2000). Providing volunteers with stewardship opportunities at the same site over time seems to help develop a stewardship ethic.

Giving back to the community through volunteering is a strong value held in our volunteer population, especially in empowerment level volunteers who feel that their work contributes to a solution to current environmental problems. Our volunteers at all levels shared a feeling that their participation does make a difference, even though it may be localized. This level of engagement may have further impacts on the community by creating a citizenry who continues to feel motivated to participate in meaningful work throughout the community (Ryan 2005; Shandas and Messer 2008). These volunteers feel that their work makes a difference, and that there are tangible benefits to the environment and the surrounding community.

Behavioral outcomes are seen as indirectly due to participation in park restoration efforts. Our stewardship volunteers indicated high levels of participation through volunteering in other restoration or environmental causes. Additionally, our most frequent volunteers have a high level of commitment to the environmental purpose of stewardship and display public pro-environmental behaviors such as advocacy 
for natural areas (Stern 2000). Commitment to the purpose of the event, rather than the PPR organization itself may be a positive benefit to the community and natural environment as a whole (Shandas and Messer 2008).

\section{Stewardship Engagement in the Community}

Empowerment level volunteers tend to participate in public pro-environmental behaviors more than less frequent volunteer participants. This engagement in public behaviors implies that volunteer stewards are involved in creating more sustainable cities, and their contribution creates a more informed citizenry, as they are involved in the process of restoring local natural environments (Shandas and Messer 2008). This engagement also establishes a place-based connection with their local environments, which gives them a personalized reason to volunteer. Additionally, they may feel a sense of belonging in their communities as a result of continued participation, and have a desire to protect natural environments for future generations (Shandas and Messer 2008). These most frequent volunteers may be self-selected people with naturally strong activist leanings, or through their service they may have become empowered by feeling that their actions make a difference in the world. Positive feedback about seeing success over time in their stewardship efforts builds sense of efficacy and can give volunteers the confidence to engage in public sustainable behaviors. Studies have shown that volunteers who participate frequently in organizations have higher confidence levels about the effectiveness of their efforts, compared with less frequent volunteers (Hines et al. 
1987). Volunteers who participate at all frequencies appear to be effective in the restoration work that they conduct, but those more frequent volunteers have larger impacts in the community (Johnson 2004). Natural area managers need to meet restoration goals, and often use volunteers to do so, but environmental awareness throughout the community may extend beyond natural areas. We see this through our own volunteers in their various behaviors, such as treating their yards as wildlife habitats and talking to neighbors about restoration. Participation may reinforce these, which creates the confidence that their efforts are effective at mitigating environmental harm.

This deep ethic of caring for the environment while supporting natural areas adds value to the local community. The PPR stewardship volunteer coordinators, when asked about this finding, mentioned that many volunteers take pride in their work and feel a sense of ownership over their local natural areas. One PPR stewardship coordinator told us about the value of this sense of volunteer empowerment, saying, "There are not many cities that you can go to and feel like you can make change, personally through a small group of people. I think that comes from ownership. A huge benefit is that we are creating stewards" (S. Braun, personal communication, 2012). This participation is unique in Portland, due to its high level of volunteer participation (Johnson 2004). Volunteer participation in stewardship increases a sense of civic engagement in the local community, and creates a larger impact in the surrounding community. 
One of the PPR volunteer coordinators indicated that feeling connected to the stewardship site might have implications for feeling a stronger sense of care over a particular park location. This sense of empowerment can be extended to other behaviors indicating concern for the parks, such as reporting vandalism (S. Braun, personal communication, 2012). She said:

"I get emails from volunteers saying they saw some graffiti over here today... You are going to say something if you see someone interrupting that process or degrading the park. So I think it helps people be a little bit stronger in their interests and their passion for a certain area... They are feeling connected into a green space because they worked there."

We see that feeling a connection to the site, feeling that one's work doing restoration makes a difference, and participating in pro-environmental behaviors together creates an empowered citizen who is a steward of natural areas. If these volunteers feel that they playing a meaningful and participatory role in repairing environmental harm, they can progress on the environmental literacy scale to become empowered volunteers (Hines et al. 1987). Volunteers may see change as a result of their efforts, even if it's on a small spatial scale, and continue their commitment to stewardship. As a result of this, stewardship volunteers might be more attracted to programs where they can observe direct evidence that environmental restoration has a worthwhile outcome (Grese et al. 2000). This highlights a need for volunteer coordinators to be explicit in stewardship outcomes, so that the result of their efforts is described in a tangible way. 


\section{Potential Survey Measurement Errors}

While we did find agreement between our volunteer responses and the environmental literacy scale, the results of our principal component analysis reveal that there is no natural grouping of volunteers' responses by frequency of volunteering. Overall, volunteers had high levels of agreement with many of our attitude questions, and very few volunteers strayed from this positive response rate. This allows for less distinction between the three levels of environmental literacy and volunteer frequency. This leads us to believe that there are two possible types of measurement error that may have impacted our results. The first is social desirability bias, in which the respondent wants to present oneself in a favorable light by underreporting undesirable attributes and over reporting desirable attributes. In this case, respondents may feel it is socially desirable to appear environmentally sensitive or aware. This bias can be fairly significant when conducting face-to-face survey interviews, as this study utilized. The respondent may sense from the interviewer that the topics are important and are things with which they should agree. If the interviewer was removed from the data collection process, different response options could be selected because the pressure to appear environmentally sensitive and involved is now absent (Groves et al. 2004).

The second type of measurement error that is introduced during this type of survey mode is acquiescence, which is the tendency by the respondent to agree to the question given (Groves et al. 2004). This measurement error is often introduced if 
the respondent is feeling rushed to get through the survey or is generally not listening carefully enough to supply the interviewer with the "true value" or an accurate response to the question. When looking at the distribution of our environmental attitude variables, a trend toward "somewhat agreeing" or "completely agreeing" with the response options is noticeable. This may indicate a response bias in the data leaning towards the higher end of the Likert scale. The overarching problem with these errors in our dataset is that answers received may not accurately describe characteristics of the respondents, which makes it difficult to draw conclusions across our target population with high levels of confidence. 


\section{Management Implications}

Portland Parks and Recreation plans to use this information to better understand their volunteers and will possibly shift the messaging of their outreach programs to resonate with potential new volunteers. Their future goals include an increase in stewardship volunteers (Portland Parks and Recreation 1999), and by understanding what motivates those volunteers, they hope to attract more first time volunteers and retain them to become frequent volunteers.

Retaining active volunteers is important for the attainment of restoration goals. Literature in the volunteer sector suggests that organizations must increasingly recognize that today's volunteers solicit specific experiences and generally will not remain with a volunteer group unless their needs are met (Wilson 2000). Our results indicate that volunteers at an intermediate level of frequency of participation and those who were at an entry level both appreciated getting to learn more about nature. Environmental reasons were the primary motivator for volunteers at all levels of environmental literacy. However, this does not mean that other factors, such as opportunities to socialize or learn about natural area restoration should not be considered when advertising stewardship events.

The most effective form of communication for notifying volunteers about work parties was an email newsletter. These often came from "Friends of Park" groups, neighborhood associations, or from PPR. Other ways people frequently heard about stewardship workdays were from the PPR website and other local volunteer- 
based websites (such as Hands On [handsonportland.org] or SOLVE [solv.org]). Many students heard about volunteering through classes, such as those focused on sustainability, where they were required to participate in a service project. Other organizations that are not direct partners with PPR were also effective at recruiting volunteers, such as church groups or mentorship programs. PPR may have success at attracting new volunteers by suggesting that current volunteers bring a neighbor or friend. This may be reflected in our survey responses to the behavior of "talking to neighbors about restoration of natural spaces." For those who already talk to their neighbors, a transition should be encouraged for them to become stewardship volunteers. This provides opportunities for volunteers to build social relationships, which may increase likelihood of returning to volunteer. One message that might be effective for this purpose is to state the opportunity to meet like-minded people while actively caring for the environment.

Providing volunteers with specific feedback about the impact of their work over time and how their work is part of an overall management strategy is important. We saw that volunteers felt empowered when it was apparent that their efforts created real change in their local natural areas. Since most volunteers indicated strong motivations to participate due to environmental reasons, this emphasis of environmental benefits would be powerful, and reinforce reasons for those volunteers to return. 


\section{Educational Opportunities}

The volunteer programs that we surveyed were primarily "drop in" volunteer programs. Other models for natural area volunteers programs involve more training and commitment over time from volunteers. For example, a "Master Stewards" type of volunteer program might mean a bigger investment in training volunteers on the part of the management agency with the expectation that volunteers will commit to work over the course of one or two years as a volunteer leader. These volunteers might also engage in monitoring of long-term ecological impacts from stewardship events, and such a long-term commitment might motivate them to volunteer with increasing frequency. Another model is a volunteer "college" program involving different workshops over the course of a weekend in native and invasive plant identification, trail maintenance, first aide, and other in depth topics. The volunteer receives a certificate for each mini course they take, and commit to a number of hours of future volunteer leadership. These trained volunteer leaders could then attend regular stewardship events and act as docents, visiting groups of volunteers and disseminating this information to those who are less experienced. This type of interaction might make entry level volunteers more comfortable socially, and will increase their education about the environmental purpose of the event.

In both of these recommended models, environmental education is a large focus to increase volunteer frequency. This follows our environmental literacy scale, assuming that by increasing frequency of volunteer participation, those volunteers will be more conscious of differing levels of environmental health, will feel a 
stronger connection to the volunteer stewardship site, and will feel like their work contributes to an improvement in ecosystem health. 


\section{Conclusions}

Within the world of volunteering for environmental causes, stewardship has a unique set of associated attitudes and behaviors. This study confirms the knowledge that caring for the environment is a primary motivation to volunteer in stewardship. We did find that volunteers become more engaged in a suite of attitudes and behaviors relating to a stewardship ethic as they volunteer more frequently. This corresponds with the environmental literacy scale, indicating that volunteer frequency can be an indication of increasing sustainable attitudes and behaviors. The behavior of volunteering strengthens this point of view, and we see larger community impacts as frequent volunteers engage in public advocacy for natural areas, and show greater levels of volunteering for a variety of environmental organizations. This information, particularly regarding motivation to volunteer, can be useful to advise future stewardship programs. Since environmental reasons were the most common motivation to volunteer, stewardship coordinators should use this information and include environmental benefits in their messaging of volunteer events.

At all levels of volunteer frequency, environmental reasons were the primary motivation to participate in volunteer stewardship. The associated attitudes and behaviors demonstrate that this environmental ethic increases with volunteer frequency. Socializing and helping community efforts were also important to our volunteers, so we see that continued participation in stewardship creates a 
volunteer community that motivates them to return over time. Overall, our volunteers clearly care for the natural spaces to which they give their time and efforts, and they value the environmental purpose of stewardship volunteering. 


\section{Recommendations for Further Research}

Future research on stewardship volunteers could focus on the personal outcomes of volunteering. Since we sought to examine the environmental and educational aspects of stewardship events, we feel that future studies might find more smallscale differences between volunteers by closely examining personal benefits derived from participation. The physical activity associated with many stewardship programs can help reduce stress and increase physical fitness. Additionally, social outcomes, such as feeling like contributions to the community are beneficial to others, may show an altruistic motivation to volunteer. These outcomes can be further studied through surveys of those who volunteer. Personal benefits such as these may be reinforced as they become motivation to continue volunteering into the future.

Stewardship can also be examined through the lens of experiential education. If the activity of volunteering in stewardship can be seen as educational in itself, use of the environmental literacy scale when examining those volunteers will be strengthened. Future studies can examine the environmental education components of stewardship programs. This may be done through volunteer surveys to determine how participants see their activities as an educational experience, or through interviews with stewardship coordinators to define how they incorporate education into their programs. An additional educational component to stewardship 
programs may attract new volunteers and retain current volunteers, as they feel empowered by their knowledge of how stewardship benefits the environment.

Finally, one key component missing from our survey was asking volunteers what period of time they have participated in volunteer stewardship. Since we found frequency of volunteering to be such a crucial factor in defining a stewardship ethic, we believe that participants who have volunteered for many years may also show this strength of care for the environment in their associated attitudes and behaviors. The length of volunteer commitment may also be related to this environmental literacy scale, and future studies should examine the relationship between duration and frequency of volunteering in stewardship. 


\section{References}

Ajzen, I., \& Fishbein, M. (1977). Attitude-Behavior Relations: A Theoretical Analysis and Review of Empirical Research. Psychological Bulletin, 84(5): 888-918.

Asah, S. T., \& Blahna, D. J. (2012). Motivational Functionalism and Urban Conservation Stewardship: Implications for Volunteer Involvement. Conservation Letters, 5(6): 470- 477.

Astin, A. W., \& Sax, L. J. (1998). How Undergraduates Are Affected by Service Participation. Journal of College Student Development, 39(3): 251-263.

Bruyere, B., \& Rappe, S. (2007). Identifying the Motivations of Environmental Volunteers. Journal of Environmental Planning and Management, 50(4): 503516.

Disinger, J. F., \& Roth, C. E. (1992). Environmental Education Research News. The Environmentalist, 12(3): 165-168.

Gooch, M. (2002). A Sense of Place : Ecological Identity as a Driver for Catchment Volunteering. Australian Journal on Volunteering: 1-11.

Grese, R. L., Kaplan, R., Ryan, R. L., \& Buxton, J. (2000). Psychological Benefits of Volunteering in Stewardship Programs. In Gobster, P.H. \& Hull, R.B. (Eds.), Restoring Nature, pp.265-280. Washington DC: Island Press.

Groves, R. M., Fowler, F. J., Couper, M. P., Lepkowski, J. M., Singer, E., \& Tourangeau, R. (2004). Survey Methodology. Hoboken, New Jersey: John Wiley \& Sons, Inc.

Hines, J. M. Hungerford, H. R., \& Tomera, A. N. (1987). Analysis and Synthesis of Research on Responsible Environmental Behavior: A Metaanalysis. Journal of Environmental Education, 18(2): 1-8.

Hungerford, H. R., \& Volk, T. L. (1990). Changing Learner Behavior through Environmental Education. Journal of Environmental Education, 21(3): 8-21.

Johnson, S. R. (2004). The Myth and Reality of Portland's Engaged Citizenry and Process-Oriented Governence. In Ozawa, C.P. (Ed.), The Portland Edge, pp. 102117. Washington, DC: Island Press.

Kaplan, S. (2000). Human Nature and Environmentally Responsible Behavior. Journal of Social Issues, 56(3): 491-508. 
Leopold, A. (1949). The Land Ethic, A Sand County Almanac. Sierra Club/ Ballantine Books, NY.

Manzo, L. C., \& Weinstein, N. D. (1987). Behavioral Commitment to Environmental Protection a Study of Active and Nonactive Members of the Sierra Club. Environment and Behavior, 19(6): 673- 694.

Marcinkowski, T. (2004). Using a Logic Model to Review and Analyze and Environmental Education Program. Washington, DC: North American Association for Environmental Education.

Miles, I., Sullivan, W. C., \& Kuo, F. E. (2000). Psychological Benefits of Volunteering for Restoration Projects. Ecological Restoration, 18(4): 218.

Mundel, K., \& Schugurensky, D. (2008). Community Based Learning and Civic Engagement; Informal Learning Among Adult Volunteers in Community Organizations. New Directions for Adult and Continuing Education, 118: 49-60.

Portland Parks and Recreation. (1999). Parks 2020 Vision. Available through: http://www.portlandoregon.gov/parks/40182

Portland Parks and Recreation. (2009). Parks 2020 Vision Progress Report 2009. Available through: http://www.portlandoregon.gov/parks/40182

Pretty, C., Bramston, P., \& Zammit, C. (2011). Assessing Environmental Stewardship Motivation. Environment and Behavior, 43(6): 776-788.

Romolini, M., Brinkley, W., \& Wolf, K. (2012). What is Urban Environmental Stewardship? Constructing a Practitioner-Derived Framework. US Forest Service Pacific Northwest Research Station. Research Note PNW-RN-566: 1-43.

Ryan, R. L., Kaplan, R., \& Grese, R. E. (2001). Predicting Volunteer Commitment in Environmental Stewardship Programmes. Journal of Environmental Planning and Management, 44(5): 629-648.

Ryan, R. L. (2005). Exploring the Effects of Environmental Experience on Attachment to Urban Natural Areas. Environment and Behavior, 37(1): 3-42.

Shandas, V., \& Messer, W. B. (2008). Fostering Green Communities Through Civic Engagement: Community-Based Environmental Stewardship in the Portland Area. Journal of the American Planning Association, 74(4): 408-418.

Stern, P. (2000). Toward a Coherent Theory of Environmentally Significant Behavior. Journal of Social Issues, 56(3): 407-424. 
Thapa, B. (2010). The Mediation Effect of Outdoor Recreation Participation on Environmental Attitude-Behavior Correspondence. The Journal of Environmental Education, 41(3): 133-150.

Wilson, J. (2000). Volunteering. Annual Review of Sociology, 26: 215-240.

Wolf, K. L., Blahna, D. J., Brinkley, W., \& Romolini, M. (2011). Environmental Stewardship Footprint Research; Linking Human Agency and Ecosystem Health in the Puget Sound Region. Urban Ecosystems, 16(1):13-32.

Worrell, R., \& Appleby, M. C. (2000). Stewardship of Natural Resources: Definition, Ethical and Practical Aspects. Journal of Agricultural and Environmental Ethics, 12: 263-277. 


\section{Appendices}

Appendix A: Survey

Questionnaire Code (to be filled in by surveyor)

Subject \#

Event Location

Activities (pulling ivy, planting, etc.)

Event size (\# volunteers)

Respondent is a volunteer
Date

Duration

Host Organization

$O R$ Respondent is a Volunteer leader

\section{All volunteers, please answer these questions:}

1. How did you hear about today's event? (check all that apply)

Portland Parks and Recreation website

Email newsletter

Social media (please name)

Someone you came here with

Other (please list)

2. About how many times per year do you participate in stewardship volunteer events?

First time as a volunteer

1-2 times

3-5 times
Other website (eg: Hands On) Friends of Park/ Neighborhood group
6-10 times

10-20 times

more than 20 times per year

3. How likely are you to volunteer again?

Not likely

Likely

Very likely

4. If you indicated not likely, what factors would make it more likely for you to volunteer again?

5. Out of the following reasons, which is the most compelling reason you volunteered today?

Please choose only one

Environmental (desire to help the environment)

Socialize (desire to meet people, I came here with my friends, desire to socialize)

Social Justice; community improvement (desire to help the community)

Educational (learning about nature and restoration)

Career (Networking or Resume building)

Working outdoors (prefer to be outdoors)

Recreational use (I like to use this place for recreation, I'd like to help it) 
6. Which environmentally-related behaviors do you now engage in or would you be likely to engage in if you had the opportunity? Please check all of the items that you engage in or would be likely to engage in.

Planting natives in your own yard

Removing invasive species in your own yard

Using environmentally friendly household products

Using pesticide in your own yard

Treating your yard as wildlife habitat

Talking to neighbors about restoration of natural spaces

Conserving water in your yard or household

Using natural park spaces in your free time

Contacting local elected officials to advocate for natural areas

These questions are about the stewardship workday:

7. Would you be more likely to attend a future stewardship event if it was at a different time of day?

_yes (If yes, please choose one: earlier later) no

What specific starting time would more suit your schedule?

8. Would you be more likely to attend an event if it was a different day of the week?

yes no

If yes, which day?

9. Do you prefer to work in groups or individually during the event? groups individually no preference

\section{This section is for Frequent Volunteers (if you have attended more than one event per year)}

10. Please indicate the degree to which this is true for you by putting the number that corresponds to your opinion before each item below. 1=completely disagree; $2=$ somewhat disagree; 3= no opinion/neutral; 4= somewhat agree; 5= completely agree

I feel a connection to this site

I do this work mostly because I like socializing

I identify myself as someone who cares about/for the environment

I like to be a part of community efforts

I would be interested in moving into a volunteer leadership role (i.e.: leading nature

walks, teaching plant identification, etc.)

I enjoy nature-based education

I am/would be interested in attending presentations about restoration ecology

I pay attention to environmental issues

I feel like my work here contributes to a solution to current environmental problems

I identify myself as an environmentalist

11. What other organizations do you volunteer for? Please list: 
12. In your own words, what impact has working on environmental restoration had on you?

13. Please indicate the degree to which this is true for you by putting the number that corresponds to your opinion next to each item below. 1= completely disagree; $2=$ somewhat disagree; 3= no opinion/neutral; 4= somewhat agree; 5= completely agree After participating in a stewardship volunteer event...

I just feel more relaxed about life

I get along better with the people in my household

I enjoy the simple things of nature more

I am more satisfied with things at work or school

I feel more safe

I feel stronger connections to other people in my community

I am able to concentrate better on my work or studies

I see more beauty in my community

I feel a greater sense of mental well-being after a volunteer event

I would guess that there is less crime in the surrounding area

\section{This Section is for First Time Volunteers Only}

14. Please indicate the degree to which this is true for you. $1=$ completely disagree; $2=$ somewhat disagree; $3=$ no opinion/neutral; 4= somewhat agree; 5=completely agree

I would come back at a later date to see the result of my efforts here

I feel like volunteering here is useful to the environment

I feel interested in the environmental purpose of today's event

I chose to volunteer at this location specifically because of the location

I feel excited about giving back to the community through volunteering

I came here with friends or to meet new people

___ If I had enough time or money, I would devote some of it to working for environmental

causes

I engage in environmentally-friendly behaviors

I enjoy leaning about the natural world

15. What in particular made you choose to volunteer at this site today?

16. What do feel you have gained from volunteering here today?

This section is for all volunteers: Your event hosts want to know...

17. Considering the purpose of today's event, did you attend out of a perceived need for physical help?

yes

no

18. Did you volunteer today because you feel there is an immediate environmental need? yes __no

19. Do you feel like the purpose of your volunteer task here today was adequately communicated to you? 
_yes __no

20. Did the message you received from the event host compel you to attend today's event? _yes __no

If so, what was the message?

21. Is there an alternative message that would be more compelling to continue volunteering in environmental restoration? __yes ___no

If so, what would that be?

22. Please indicate your preferred order of the following components in an event (Place a 1 next to the event you think should come first, a 2 next to the second, etc.) and your preferred percentage of time spent on each.

Work _ _ \% Time spent

Educational component ___ \% Time spent

Socializing

$\%$ Time spent

\section{All volunteers, please answer the below questions:}

23. What is your age?

24 . What is your gender?

25 . What is your home zip code?

26. How do you identify most strongly?

Black or African-American

Hispanic

American Indian or Alaskan Native

Native Hawaiian or other Pacific Islander

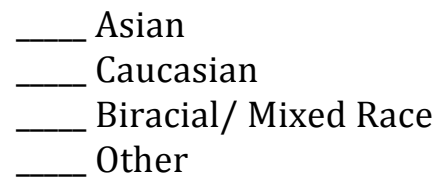

27. Which of the following best describes the highest level of education you have completed? did not complete high school high school diploma or equivalent some college college graduate graduate or professional degree

28. What is your current employment situation? part-time employment full time employment home duties retired student or training program unemployed other

29. What is the total income for your household?

under $\$ 20,000$

$\$ 140,000$ $\$ 20,000$ to $\$ 40,000$

$\$ 160,000$
_ $\$ 60,000$ to $\$ 80,000$

$\$ 80,000$ to $\$ 100,000$
$\$ 120,000$ to

$\$ 140,000$ to 
30. Number of people in your household:

31. How much time did it take for you to travel to today's event? hours minutes

32. What mode(s) of transportation did you use? What percentage of the travel time was spent on each? motor vehicle $\%$ bus walk $\%$

$\begin{array}{rr}\text { bike } & \text { other } \\ -\% & \ldots\end{array}$

33. If you traveled by car, how many people were in the car with you (carpool)?

34. Will you travel straight home after today's event? yes no

35. Please list any materials, equipment or food you contributed for today's event, and their estimated cost

\begin{tabular}{|l|l|}
\hline List specific materials, equipment, food below & Estimated cost or value \\
\hline & \\
\hline & \\
\hline & \\
\hline & \\
\hline
\end{tabular}

Thank you very much! 


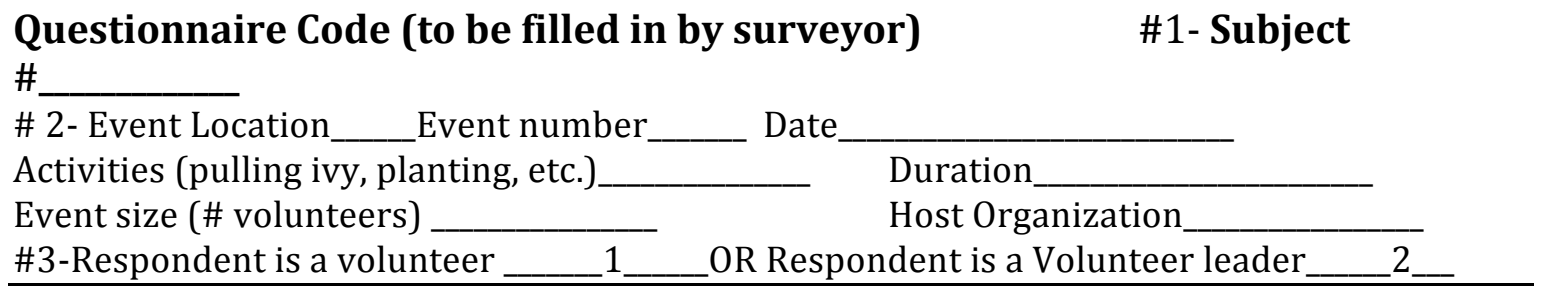

\section{All volunteers, please answer these questions:}

\#4. How did you hear about today's event? (check all that apply)
1_Portland Parks and Recreation website
2_Email newsletter
5__Other website (eg: Hands On)
3___social media (please name)
4_Someone you came here with
_\#5__other (please list)
written answer
6__Friends of Park/ Neighborhood group

\#6- About how many times per year do you participate in stewardship volunteer events?
1_First time as a volunteer
2_1-2 times
_4_6-10 times
3_3-5 times
5_10-20 times
6_more than 20 times per year

\#7. How likely are you to volunteer again?

1___Not likely
_2__Likely
3__Very likely

\#8. If you indicated not likely, what factors would make it more likely for you to volunteer again?

written answer

\#9. Out of the following reasons, which is the most compelling reason you volunteered today?

Please choose only one

1__Environmental (desire to help the environment)

_2_Socialize (desire to meet people, I came here with my friends, desire to socialize)

_.__Social Justice; community improvement (desire to help the community)

_4_Educational (learning about nature and restoration)

5__Career (Networking or Resume building)

_6_Working outdoors (prefer to be outdoors)

_ 7 _ Recreational use (I like to use this place for recreation, I'd like to help it)

Which environmentally-related behaviors do you now engage in or would you be likely to engage in if you had the opportunity? Please check all of the items that you engage in or would be likely to engage in.

\#10a__ Planting natives in your own yard $1=$ yes, $0=$ no

$\# 10 b \_$Removing invasive species in your own yard $1=$ yes, $0=$ no

_\#10c__ Using environmentally friendly household products $1=$ yes, $0=$ no 
\#10d__ Using pesticide in your own yard $1=$ yes, $0=$ no

\#10e_ Treating your yard as wildlife habitat $1=$ yes, $0=$ no

\#10f_- Talking to neighbors about restoration of natural spaces $1=y e s, 0=$ no

\#10g_Conserving water in your yard or household $1=$ yes, $0=$ no

$\# 10 \mathrm{~h}$ _ Using natural park spaces in your free time $1=$ yes, $0=$ no

\#10i__ Contacting local elected officials to advocate for natural areas $\mathbf{1}=\mathbf{y e s ,} \mathbf{0}=\mathbf{n o}$

These questions are about the stewardship workday:

\#11. Would you be more likely to attend a future stewardship event if it was at a different time of day?

_1_yes (If yes, please choose one: _3__earlier _ _ __later) _ 2_no

\#12. What specific starting time would more suit your schedule?_written time

\#13. Would you be more likely to attend an event if it was a different day of the week?

_1_yes _2_no

\#14. If yes, which day? written day

\#15. Do you prefer to work in groups or individually during the event?

__ 1_ groups ____ individually ___ _ no preference

\section{This section is for Frequent Volunteers (if you have attended more than one event per year)}

Please indicate the degree to which this is true for you by putting the number that corresponds to your opinion before each item below. 1= completely disagree; $2=$ somewhat disagree; $3=$ no opinion/neutral; 4= somewhat agree; 5= completely agree \#16__(1-5)_ I feel a connection to this site

\#17__(1-5)__ I do this work mostly because I like socializing

\#18_(1-5)___ I identify myself as someone who cares about/for the environment

\#19_(1-5)__ I like to be a part of community efforts

\#20_(1-5)___ I would be interested in moving into a volunteer leadership role (i.e.: leading nature walks, teaching plant identification, etc.)

\#21_(1-5)___ I enjoy nature-based education

\#22_(1-5)___ I am/would be interested in attending presentations about restoration

ecology

\#23_(1-5)___ I pay attention to environmental issues

\#24_(1-5)___ I feel like my work here contributes to a solution to current environmental

problems

\#25_(1-5)___ I identify myself as an environmentalist

\#26. What other organizations do you volunteer for? Please list: written answer

\#27. In your own words, what impact has working on environmental restoration had on you? written answer (and assign code using coding protocol)

Please indicate the degree to which this is true for you by putting the number that corresponds to your opinion next to each item below. $1=$ completely disagree; $2=$ somewhat disagree; 3= no opinion/neutral; 4= somewhat agree; 5= completely agree 
After participating in a stewardship volunteer event...

\#28_(1-5)__ _ I just feel more relaxed about life

\#29_(1-5)__ I get along better with the people in my household

\#30_(1-5)_ I enjoy the simple things of nature more

\#31_(1-5)_ I am more satisfied with things at work or school

\#32_(1-5)_I feel more safe

\#33_(1-5)_ I feel stronger connections to other people in my community

\#34__(1-5)__ am able to concentrate better on my work or studies

\#35__(1-5)_I see more beauty in my community

\#36_(1-5)_I feel a greater sense of mental well-being after a volunteer event

\#37_(1-5) I would guess that there is less crime in the surrounding area

\section{This Section is for First Time Volunteers Only}

14. Please indicate the degree to which this is true for you. $1=$ completely disagree; $2=$ somewhat disagree; $3=$ no opinion/neutral; $4=$ somewhat agree; $5=$ completely agree \#38_(1-5)__ _ I would come back at a later date to see the result of my efforts here \#39_(1-5)__ I feel like volunteering here is useful to the environment \#40_(1-5)__ I feel interested in the environmental purpose of today's event \#41_(1-5)__ I I chose to volunteer at this location specifically because of the location \#42_(1-5)__ I feel excited about giving back to the community through volunteering \#43_(1-5)__ I came here with friends or to meet new people \#44_(1-5) If I had enough time or money, I would devote some of it to working for environmental causes

\#45_(1-5)__ I engage in environmentally-friendly behaviors

\#46_(1-5)__ I enjoy learning about the natural world

\#47. What in particular made you choose to volunteer at this site today? written answer

\#48. What do feel you have gained from volunteering here today? written answer

This section is for all volunteers: Your event hosts want to know... \#49. Considering the purpose of today's event, did you attend out of a perceived need for physical help?

_1_yes __2_no

\#50. Did you volunteer today because you feel there is an immediate environmental need? _1_yes __2_no

\#51 Do you feel like the purpose of your volunteer task here today was adequately communicated to you?_1_yes__2_no

\#52. Did the message you received from the event host compel you to attend today's event? _1_yes_2_no

\#53 If so, what was the message? written answer

\#54. Is there an alternative message that would be more compelling to continue volunteering in environmental restoration?_1_yes _2_no 
\#55If so, what would that be?

written answer

. Please indicate your preferred order for the following component in an event Place a 1 next to the event you think should come first, a 2 next to the second, etc.

and preferred percentage of time spent in each.

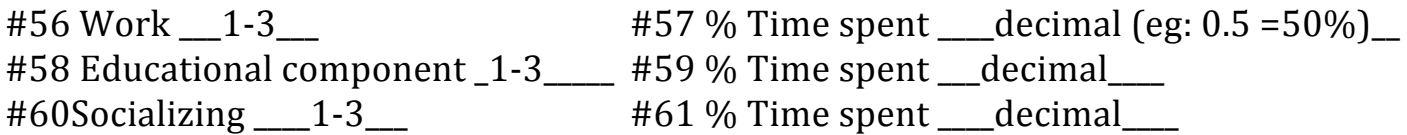

\section{All volunteers, please answer the below questions:}

\#62 What is your age? _\#

\#63 What is your gender? __ M or F

\#64. What is your home zip code? _ 5 digit number

\#65 How do you identify most strongly?

_1__ Black or African-American

_2__ Hispanic

_3_ American Indian or Alaskan Native

__ _ Native Hawaiian or other Pacific Islander

_6_ Caucasian
_ ${ }^{5}$ _- Biracial/ Mixed Race
_ Other

\#66. Which of the following best describes the highest level of education you have completed?

_1__ did not complete high school

_2_ high school diploma or equivalent

_3_ some college

_4_ college graduate

_5_ graduate or professional degree

\#67. What is your current employment situation?

_1_ part-time employment

_2__ full time employment

_4_ home duties

3 3_retired

_5_student or training program

_6_ unemployed __ 7 __ other

\#68. What is the total income for your household?

\begin{tabular}{|c|c|c|}
\hline -1_under $\$ 20,000$ & _4__ $\$ 60,000$ to $\$ 80,000$ & ${ }^{7} \_\$ 120,000$ to \\
\hline$\$ 140,000$ & & \\
\hline $\begin{array}{l}2 \\
\$ 160,000\end{array} \$ 20,000$ to $\$ 40,000$ & _5_\$80,000 to $\$ 100,000$ & $-8 \_\$ 1$ \\
\hline $\begin{array}{l}3{ }^{3}-\$ 40,000 \text { to } \$ 60,000 \\
\$ 160,000\end{array}$ & _6__ $\$ 100,000$ to $\$ 120,000$ & -9_- more than \\
\hline
\end{tabular}

\#69. Number of people in your household:

\# 
\#70. How much time did it take for you to travel to today's event? Hours = whole number, decimal $=\%$ of an hour

What mode(s) of transportation did you use? What percentage of the travel time was spent on each?

\#71 motor vehicle

\#72 bus

\#73 walk

\#74 bike

\#75 other

enter as decimal

$\%$

$\ldots$

- $\%$

$\ldots$

$\%$

\#76 If you traveled by car, how many people were in the car with you (carpool)?

$\#$

\#77. Will you travel straight home after today's event? __ __ yes ____ no

Please list any materials, equipment or food you contributed for today's event, and their estimated cost (enter item on one column, repeat as needed)

\begin{tabular}{|l|l|}
\hline $\begin{array}{l}\text { List specific materials, equipment, food } \\
\text { below }\end{array}$ & Estimated cost or value \\
\hline$\# 78$ written answer & $\# 79 \$ \_--$ \\
\hline$\# 80$ & $\# 81$ \\
\hline
\end{tabular}


Appendix C: Event information

\begin{tabular}{|l|l|l|}
\hline Event Number & 1 & 2 \\
\hline Event Location & Tideman Johnson Park & Holman Lane, Forest Park \\
\hline Activities & Planting & Pulling ivy \& planting \\
\hline Date & 4-Feb-12 & 4-Feb-12 \\
\hline Duration & 3 hours & 3 hours \\
\hline Event Size & 14 & 30 \\
\hline $\begin{array}{l}\text { Volunteers } \\
\text { Surveyed }\end{array}$ & 11 & 7 \\
\hline $\begin{array}{l}\text { Host } \\
\text { Organization }\end{array}$ & $\begin{array}{l}\text { PPR \& Friends of Tideman } \\
\text { Johnson }\end{array}$ & Forest Park Conservancy \\
\hline
\end{tabular}

\begin{tabular}{|l|l|l|}
\hline Event Number & 3 & 4 \\
\hline Event Location & Terwilliger Wildlands & Powell Butte \\
\hline Activities & Invasive removal, planting & Trail Maintenance \\
\hline Date & 11 -Feb-12 & $11-$ Feb-12 \\
\hline Duration & 3 hours & 3 hours \\
\hline Event Size & 15 & 20 \\
\hline $\begin{array}{l}\text { Volunteers } \\
\text { Surveyed }\end{array}$ & 13 & 6 \\
\hline $\begin{array}{l}\text { Host } \\
\text { Organization }\end{array}$ & PPR & PPR \\
\hline
\end{tabular}

\begin{tabular}{|l|l|l|}
\hline Event Number & 5 & 6 \\
\hline Event Location & Butterfly Park & Marquam Park \\
\hline Activities & Planting & Invasive removal, planting \\
\hline Date & $18-$ Feb-12 & $25-$ Feb-12 \\
\hline Duration & 3 hours & 3 hours \\
\hline Event Size & 16 & 25 \\
\hline $\begin{array}{l}\text { Volunteers } \\
\text { Surveyed }\end{array}$ & 9 & 9 \\
\hline $\begin{array}{l}\text { Host } \\
\text { Organization }\end{array}$ & PPR & PPR \\
\hline
\end{tabular}




\begin{tabular}{|l|l|l|}
\hline Event Number & 7 & 8 \\
\hline Event Location & Forest Park & SE 128, Springwater Corridor \\
\hline Activities & Ivy Pulling & Mulching \\
\hline Date & 3-Mar-12 & 10 -Mar-12 \\
\hline Duration & 3 hours & 3 hours \\
\hline Event Size & 20 & 4 \\
\hline $\begin{array}{l}\text { Volunteers } \\
\text { Surveyed }\end{array}$ & 10 & 4 \\
\hline $\begin{array}{l}\text { Host } \\
\text { Organization }\end{array}$ & PPR \& No Ivy League & PPR \\
\hline
\end{tabular}

\begin{tabular}{|l|l|l|}
\hline Event Number & 9 & 10 \\
\hline Event Location & SE 82, Springwater Corridor & Powers Marine Park \\
\hline Activities & Planting & Planting \\
\hline Date & 10-Mar-12 & 17 -Mar-12 \\
\hline Duration & 3 hours & 3 hours \\
\hline Event Size & 20 & 6 \\
\hline $\begin{array}{l}\text { Volunteers } \\
\text { Surveyed }\end{array}$ & 4 & 5 \\
\hline $\begin{array}{l}\text { Host } \\
\text { Organization }\end{array}$ & PPR & PPR \\
\hline
\end{tabular}

\begin{tabular}{|l|l|l|}
\hline Event Number & 11 & 12 \\
\hline Event Location & Forest Park, Upper Macleay & Woods Memorial Park \\
\hline Activities & Ivy Pulling & Ivy Pulling \\
\hline Date & 21 -Mar-12 & 24-Mar-12 \\
\hline Duration & 3 hours & 3 hours \\
\hline Event Size & 6 & 8 \\
\hline $\begin{array}{l}\text { Volunteers } \\
\text { Surveyed }\end{array}$ & 2 & 8 \\
\hline $\begin{array}{l}\text { Host } \\
\text { Organization }\end{array}$ & PPR \& No Ivy League & PPR \\
\hline
\end{tabular}




\begin{tabular}{|l|l|l|}
\hline Event Number & 13 & 14 \\
\hline Event Location & Forest Park, Dogwood Trail & Sellwood Riverfront Park \\
\hline Activities & Trail Maintenance & Fence building \\
\hline Date & 29-Mar-12 & 31 -Mar-12 \\
\hline Duration & 3 hours & 3 hours \\
\hline Event Size & 11 & 5 \\
\hline $\begin{array}{l}\text { Volunteers } \\
\text { Surveyed }\end{array}$ & 10 & 5 \\
\hline $\begin{array}{l}\text { Host } \\
\text { Organization }\end{array}$ & Forest Park Conservancy & PPR \& Surfrider Foundation \\
\hline
\end{tabular}

\begin{tabular}{|l|l|l|}
\hline Event Number & 15 & 16 \\
\hline Event Location & April Hill Park & Errol Heights Natural Area \\
\hline Activities & Planting \& Invasive Removal & Trail Maintenance \\
\hline Date & 14-Apr-12 & 21-Apr-12 \\
\hline Duration & 3 hours & 3 hours \\
\hline Event Size & 10 & 5 \\
\hline $\begin{array}{l}\text { Volunteers } \\
\text { Surveyed }\end{array}$ & 8 & 5 \\
\hline $\begin{array}{l}\text { Host } \\
\text { Organization }\end{array}$ & PPR & PPR \\
\hline
\end{tabular}

\begin{tabular}{|l|l|l|}
\hline Event Number & 17 & 18 \\
\hline Event Location & Mt. Tabor & Ross Island \\
\hline Activities & Invasive Removal & Invasive Removal \\
\hline Date & $28-$ Apr-12 & 9-Jun-12 \\
\hline Duration & 3 hours & 4 hours \\
\hline Event Size & 26 & 9 \\
\hline $\begin{array}{l}\text { Volunteers } \\
\text { Surveyed }\end{array}$ & 12 & 3 \\
\hline $\begin{array}{l}\text { Host } \\
\text { Organization }\end{array}$ & Friends of Mt. Tabor & PPR \& Willamette Riverkeeper \\
\hline
\end{tabular}




\section{Appendix D: Summary Statistics of Attitudes and Behaviors}

Entry Level

\begin{tabular}{|l|l|l|l|l|l|}
\hline Question & $\begin{array}{l}\text { Plant } \\
\text { Natives }\end{array}$ & $\begin{array}{l}\text { Remove } \\
\text { Invasives }\end{array}$ & $\begin{array}{l}\text { Uses } \\
\text { Green } \\
\text { House } \\
\text { Products }\end{array}$ & $\begin{array}{l}\text { Uses } \\
\text { Pesticide }\end{array}$ & $\begin{array}{l}\text { Yard as } \\
\text { Habitat }\end{array}$ \\
\hline $\begin{array}{l}\text { Question } \\
\text { Number }\end{array}$ & q10a & q10b & q10c & q10d & q10e \\
\hline $\begin{array}{l}\text { Number of } \\
\text { Responses }\end{array}$ & 42 & 42 & 42 & 42 & 42 \\
\hline Mean & 0.86 & 0.90 & 0.88 & 0.10 & 0.76 \\
\hline $\begin{array}{l}\text { Standard } \\
\text { Deviation }\end{array}$ & 0.35 & 0.30 & 0.33 & 0.30 & 0.43 \\
\hline Minimum & 0 & 0 & 0 & 0 & 0 \\
\hline Maximum & 1 & 1 & 1 & 1 & 1 \\
\hline
\end{tabular}

\begin{tabular}{|l|l|l|l|l|}
\hline Question & $\begin{array}{l}\text { Talking to } \\
\text { Neighbors }\end{array}$ & $\begin{array}{l}\text { Conserving } \\
\text { Water }\end{array}$ & $\begin{array}{l}\text { Using Park } \\
\text { Spaces }\end{array}$ & $\begin{array}{l}\text { Advocate } \\
\text { for Natural } \\
\text { Areas }\end{array}$ \\
\hline $\begin{array}{l}\text { Question } \\
\text { Number }\end{array}$ & q10f & q10g & q10h & q10i \\
\hline $\begin{array}{l}\text { Number of } \\
\text { Responses }\end{array}$ & 42 & 42 & 42 & 42 \\
\hline Mean & 0.43 & 0.95 & 0.98 & 0.29 \\
\hline $\begin{array}{l}\text { Standard } \\
\text { Deviation }\end{array}$ & 0.50 & 0.22 & 0.15 & 0.46 \\
\hline Minimum & 0 & 0 & 0 & 0 \\
\hline Maximum & 1 & 1 & 1 & 1 \\
\hline
\end{tabular}

\begin{tabular}{|l|l|l|l|l|l|}
\hline Question & $\begin{array}{l}\text { Connection } \\
\text { to Site }\end{array}$ & $\begin{array}{l}\text { Enjoy } \\
\text { Socializing }\end{array}$ & $\begin{array}{l}\text { Cares about } \\
\text { Environment }\end{array}$ & $\begin{array}{l}\text { Enjoys } \\
\text { Community } \\
\text { Effort }\end{array}$ & $\begin{array}{l}\text { Interest in } \\
\text { Leadership }\end{array}$ \\
\hline $\begin{array}{l}\text { Question } \\
\text { Number }\end{array}$ & $\mathrm{q} 16$ & $\mathrm{q} 17$ & $\mathrm{q} 18$ & $\mathrm{q} 19$ & $\mathrm{q} 20$ \\
\hline $\begin{array}{l}\text { Number of } \\
\text { Response }\end{array}$ & 41 & 12 & 41 & 41 & 12 \\
\hline Mean & 3.27 & 2.92 & 4.34 & 4.54 & 3.08 \\
\hline $\begin{array}{l}\text { Standard } \\
\text { Deviation }\end{array}$ & 1.52 & 0.90 & 0.79 & 0.64 & 1.38 \\
\hline Minimum & 1 & 2 & 1 & 3 & 1 \\
\hline Maximum & 5 & 5 & 5 & 5 & 5 \\
\hline
\end{tabular}




\begin{tabular}{|l|l|l|l|l|l|}
\hline Question & $\begin{array}{l}\text { Enjoy } \\
\text { Nature Ed }\end{array}$ & $\begin{array}{l}\text { Interest in } \\
\text { Restoration } \\
\text { Ecology }\end{array}$ & $\begin{array}{l}\text { Pays } \\
\text { Attention to } \\
\text { Issues }\end{array}$ & $\begin{array}{l}\text { Work as } \\
\text { Solution }\end{array}$ & $\begin{array}{l}\text { Environmentalist } \\
\text { ID }\end{array}$ \\
\hline $\begin{array}{l}\text { Question } \\
\text { Number }\end{array}$ & $\mathrm{q} 21$ & $\mathrm{q} 22$ & $\mathrm{q} 23$ & $\mathrm{q} 24$ & $\mathrm{q} 25$ \\
\hline $\begin{array}{l}\text { Number of } \\
\text { Responses }\end{array}$ & 41 & 12 & 12 & 12 & 11 \\
\hline Mean & 4.46 & 3.92 & 4.42 & 4.17 & 4.27 \\
\hline $\begin{array}{l}\text { Standard } \\
\text { Deviation }\end{array}$ & 0.67 & 1.16 & 0.67 & 1.11 & 1.01 \\
\hline Minimum & 3 & 2 & 3 & 2 & 2 \\
\hline Maximum & 5 & 5 & 5 & 5 & 5 \\
\hline
\end{tabular}

Ownership Level

\begin{tabular}{|l|l|l|l|l|l|}
\hline Question & $\begin{array}{l}\text { Plant } \\
\text { Natives }\end{array}$ & $\begin{array}{l}\text { Remove } \\
\text { Invasives }\end{array}$ & $\begin{array}{l}\text { Uses } \\
\text { Green } \\
\text { House } \\
\text { Products }\end{array}$ & $\begin{array}{l}\text { Uses } \\
\text { Pesticide }\end{array}$ & $\begin{array}{l}\text { Yard as } \\
\text { Habitat }\end{array}$ \\
\hline $\begin{array}{l}\text { Question } \\
\text { Number }\end{array}$ & q10a & q10b & q10c & q10d & q10e \\
\hline $\begin{array}{l}\text { Number of } \\
\text { Responses }\end{array}$ & 46 & 46 & 46 & 46 & 46 \\
\hline Mean & 0.96 & 1.00 & 0.98 & 0.07 & 0.80 \\
\hline $\begin{array}{l}\text { Standard } \\
\text { Deviation }\end{array}$ & 0.21 & 0.00 & 0.15 & 0.25 & 0.40 \\
\hline Minimum & 0 & 1 & 0 & 0 & 0 \\
\hline Maximum & 1 & 1 & 1 & 1 & 1 \\
\hline
\end{tabular}

\begin{tabular}{|l|l|l|l|l|}
\hline Question & $\begin{array}{l}\text { Talking to } \\
\text { Neighbors }\end{array}$ & $\begin{array}{l}\text { Conserving } \\
\text { Water }\end{array}$ & $\begin{array}{l}\text { Using Park } \\
\text { Spaces }\end{array}$ & $\begin{array}{l}\text { Advocate } \\
\text { for Natural } \\
\text { Areas }\end{array}$ \\
\hline $\begin{array}{l}\text { Question } \\
\text { Number }\end{array}$ & q10f & $\mathrm{q} 10 \mathrm{~g}$ & $\mathrm{q} 10 \mathrm{~h}$ & $\mathrm{q} 10 \mathrm{i}$ \\
\hline $\begin{array}{l}\text { Number of } \\
\text { Responses }\end{array}$ & 46 & 46 & 46 & 46 \\
\hline Mean & 0.52 & 0.91 & 1.00 & 0.54 \\
\hline $\begin{array}{l}\text { Standard } \\
\text { Deviation }\end{array}$ & 0.51 & 0.28 & 0.00 & 0.50 \\
\hline Minimum & 0 & 0 & 1 & 0 \\
\hline Maximum & 1 & 1 & 1 & 1 \\
\hline
\end{tabular}




\begin{tabular}{|l|l|l|l|l|l|}
\hline Question & $\begin{array}{l}\text { Connection } \\
\text { to Site }\end{array}$ & $\begin{array}{l}\text { Enjoy } \\
\text { Socializing }\end{array}$ & $\begin{array}{l}\text { Cares about } \\
\text { Environment }\end{array}$ & $\begin{array}{l}\text { Enjoys } \\
\text { Community } \\
\text { Effort }\end{array}$ & $\begin{array}{l}\text { Interest in } \\
\text { Leadership }\end{array}$ \\
\hline $\begin{array}{l}\text { Question } \\
\text { Number }\end{array}$ & $\mathrm{q} 16$ & $\mathrm{q} 17$ & $\mathrm{q} 18$ & $\mathrm{q} 19$ & $\mathrm{q} 20$ \\
\hline $\begin{array}{l}\text { Number of } \\
\text { Responses }\end{array}$ & 45 & 45 & 45 & 45 & 45 \\
\hline Mean & 4.07 & 2.58 & 4.71 & 4.53 & 2.91 \\
\hline $\begin{array}{l}\text { Standard } \\
\text { Deviation }\end{array}$ & 1.19 & 0.99 & 0.59 & 0.59 & 1.46 \\
\hline Minimum & 1 & 1 & 3 & 3 & 1 \\
\hline Maximum & 5 & 5 & 5 & 5 & 5 \\
\hline
\end{tabular}

\begin{tabular}{|l|l|l|l|l|l|}
\hline Question & $\begin{array}{l}\text { Enjoy } \\
\text { Nature Ed }\end{array}$ & $\begin{array}{l}\text { Interest in } \\
\text { Restoration } \\
\text { Ecology }\end{array}$ & $\begin{array}{l}\text { Pays } \\
\text { Attention to } \\
\text { Issues }\end{array}$ & $\begin{array}{l}\text { Work as } \\
\text { Solution }\end{array}$ & $\begin{array}{l}\text { Environmentalist } \\
\text { ID }\end{array}$ \\
\hline $\begin{array}{l}\text { Question } \\
\text { Number }\end{array}$ & $\mathrm{q} 21$ & $\mathrm{q} 22$ & $\mathrm{q} 23$ & $\mathrm{q} 24$ & $\mathrm{q} 25$ \\
\hline $\begin{array}{l}\text { Number of } \\
\text { Responses }\end{array}$ & 45 & 45 & 45 & 45 & 45 \\
\hline Mean & 4.49 & 4.02 & 4.49 & 4.33 & 4.31 \\
\hline $\begin{array}{l}\text { Standard } \\
\text { Deviation }\end{array}$ & 0.84 & 1.10 & 0.59 & 0.80 & 1.00 \\
\hline Minimum & 2 & 1 & 3 & 2 & 1 \\
\hline Maximum & 5 & 5 & 5 & 5 & 5 \\
\hline
\end{tabular}

Empowerment Level

\begin{tabular}{|l|l|l|l|l|l|}
\hline Question & $\begin{array}{l}\text { Plant } \\
\text { Natives }\end{array}$ & $\begin{array}{l}\text { Remove } \\
\text { Invasives }\end{array}$ & $\begin{array}{l}\text { Uses } \\
\text { Green } \\
\text { House } \\
\text { Products }\end{array}$ & $\begin{array}{l}\text { Uses } \\
\text { Pesticide }\end{array}$ & $\begin{array}{l}\text { Yard as } \\
\text { Habitat }\end{array}$ \\
\hline $\begin{array}{l}\text { Question } \\
\text { Number }\end{array}$ & q10a & q10b & q10c & q10d & q10e \\
\hline $\begin{array}{l}\text { Number of } \\
\text { Responses }\end{array}$ & 43 & 43 & 43 & 43 & 43 \\
\hline Mean & 0.91 & 0.95 & 0.93 & 0.09 & 0.81 \\
\hline $\begin{array}{l}\text { Standard } \\
\text { Deviation }\end{array}$ & 0.29 & 0.21 & 0.26 & 0.29 & 0.39 \\
\hline Minimum & 0 & 0 & 0 & 0 & 0 \\
\hline Maximum & 1 & 1 & 1 & 1 & 1 \\
\hline
\end{tabular}




\begin{tabular}{|l|l|l|l|l|}
\hline Question & $\begin{array}{l}\text { Talking to } \\
\text { Neighbors }\end{array}$ & $\begin{array}{l}\text { Conserving } \\
\text { Water }\end{array}$ & $\begin{array}{l}\text { Using Park } \\
\text { Spaces }\end{array}$ & $\begin{array}{l}\text { Advocate } \\
\text { for Natural } \\
\text { Areas }\end{array}$ \\
\hline $\begin{array}{l}\text { Question } \\
\text { Number }\end{array}$ & q10f & q10g & q10h & q10i \\
\hline $\begin{array}{l}\text { Number of } \\
\text { Responses }\end{array}$ & 43 & 43 & 43 & 43 \\
\hline Mean & 0.56 & 0.86 & 0.91 & 0.56 \\
\hline $\begin{array}{l}\text { Standard } \\
\text { Deviation }\end{array}$ & 0.50 & 0.35 & 0.29 & 0.50 \\
\hline Minimum & 0 & 0 & 0 & 0 \\
\hline Maximum & 1 & 1 & 1 & 1 \\
\hline
\end{tabular}

\begin{tabular}{|l|l|l|l|l|l|}
\hline Question & $\begin{array}{l}\text { Connection } \\
\text { to Site }\end{array}$ & $\begin{array}{l}\text { Enjoy } \\
\text { Socializing }\end{array}$ & $\begin{array}{l}\text { Cares about } \\
\text { Environment }\end{array}$ & $\begin{array}{l}\text { Enjoys } \\
\text { Community } \\
\text { Effort }\end{array}$ & $\begin{array}{l}\text { Interest in } \\
\text { Leadership }\end{array}$ \\
\hline $\begin{array}{l}\text { Question } \\
\text { Number }\end{array}$ & $\mathrm{q} 16$ & $\mathrm{q} 17$ & $\mathrm{q} 18$ & $\mathrm{q} 19$ & $\mathrm{q} 20$ \\
\hline $\begin{array}{l}\text { Number of } \\
\text { Responses }\end{array}$ & 43 & 43 & 43 & 43 & 43 \\
\hline Mean & 4.58 & 3.00 & 4.79 & 4.58 & 3.58 \\
\hline $\begin{array}{l}\text { Standard } \\
\text { Deviation }\end{array}$ & 0.66 & 1.20 & 0.47 & 0.73 & 1.43 \\
\hline Minimum & 3 & 1 & 3 & 2 & 1 \\
\hline Maximum & 5 & 5 & 5 & 5 & 5 \\
\hline
\end{tabular}

\begin{tabular}{|l|l|l|l|l|l|}
\hline Question & $\begin{array}{l}\text { Enjoy } \\
\text { Nature Ed }\end{array}$ & $\begin{array}{l}\text { Interest in } \\
\text { Restoration } \\
\text { Ecology }\end{array}$ & $\begin{array}{l}\text { Pays } \\
\text { Attention to } \\
\text { Issues }\end{array}$ & $\begin{array}{l}\text { Work as } \\
\text { Solution }\end{array}$ & $\begin{array}{l}\text { Environmentalist } \\
\text { ID }\end{array}$ \\
\hline $\begin{array}{l}\text { Question } \\
\text { Number }\end{array}$ & $\mathrm{q} 21$ & $\mathrm{q} 22$ & $\mathrm{q} 23$ & $\mathrm{q} 24$ & $\mathrm{q} 25$ \\
\hline $\begin{array}{l}\text { Number of } \\
\text { Responses }\end{array}$ & 43 & 43 & 43 & 43 & 43 \\
\hline Mean & 4.56 & 3.98 & 4.63 & 4.19 & 4.21 \\
\hline $\begin{array}{l}\text { Standard } \\
\text { Deviation }\end{array}$ & 0.80 & 1.16 & 0.72 & 0.93 & 1.12 \\
\hline Minimum & 2 & 1 & 2 & 1 & 1 \\
\hline Maximum & 5 & 5 & 5 & 5 & 5 \\
\hline
\end{tabular}




\section{Appendix E: Full Generalized Linear Model Outputs}

Frequency Predictions

\begin{tabular}{|l|l|l|l|}
\hline $\begin{array}{l}\text { Predictor (Attitude/ } \\
\text { Behavior) }\end{array}$ & Response & p-value & $\begin{array}{l}\text { Relationship } \\
\text { Direction }\end{array}$ \\
\hline Q16- Connection to site & $\begin{array}{l}\text { Q6- Frequency of } \\
\text { volunteering }\end{array}$ & $4.94 \times 10^{-8}$ & + \\
\hline $\begin{array}{l}\text { Q10g- Conserving water } \\
\text { in yard/home }\end{array}$ & $\begin{array}{l}\text { Q6- Frequency of } \\
\text { volunteering }\end{array}$ & 0.0592 & - \\
\hline $\begin{array}{l}\text { Q10i- Advocating for } \\
\text { natural areas }\end{array}$ & $\begin{array}{l}\text { Q6- Frequency of } \\
\text { volunteering }\end{array}$ & 0.0008 & + \\
\hline
\end{tabular}

Entry Level- Predicting volunteer behaviors by reported attitudes

\begin{tabular}{|l|l|l|l|}
\hline Predictor (Attitude) & Response (Behavior) & p-value & $\begin{array}{l}\text { Relationship } \\
\text { Direction }\end{array}$ \\
\hline $\begin{array}{l}\text { Q18- Care about } \\
\text { environment }\end{array}$ & $\begin{array}{l}\text { Q10a- Planting natives at } \\
\text { home }\end{array}$ & 0.0323 & + \\
\hline $\begin{array}{l}\text { Q21- Enjoying nature- } \\
\text { based education }\end{array}$ & $\begin{array}{l}\text { Q10b- Removing invasive } \\
\text { species at home }\end{array}$ & 0.0471 & + \\
\hline $\begin{array}{l}\text { Q18- Care about } \\
\text { environment }\end{array}$ & $\begin{array}{l}\text { Q10f- Talking to neighbors } \\
\text { about restoration }\end{array}$ & 0.0214 & + \\
\hline $\begin{array}{l}\text { Q18- Care about } \\
\text { environment }\end{array}$ & $\begin{array}{l}\text { Q10i- Advocating for natural } \\
\text { areas }\end{array}$ & 0.0867 & + \\
\hline
\end{tabular}

Entry Level- Predicting volunteer attitudes by reported behaviors

\begin{tabular}{|l|l|l|l|}
\hline Predictor (Behavior) & Response (Attitude) & p-value & $\begin{array}{l}\text { Relationship } \\
\text { Direction }\end{array}$ \\
\hline $\begin{array}{l}\text { Q10a- Planting natives at } \\
\text { home }\end{array}$ & Q18- Care about environment & 0.0003 & + \\
\hline $\begin{array}{l}\text { Q10f- Talking to } \\
\text { neighbors about } \\
\text { restoration }\end{array}$ & $\begin{array}{l}\text { Q19- Liking community } \\
\text { efforts }\end{array}$ & 0.0299 & + \\
\hline $\begin{array}{l}\text { Q10a- Planting natives at } \\
\text { home }\end{array}$ & $\begin{array}{l}\text { Q21- Enjoying nature-based } \\
\text { education }\end{array}$ & 0.0113 & + \\
\hline
\end{tabular}

Ownership Level- Predicting volunteer behaviors by reported attitudes

\begin{tabular}{|l|l|l|l|}
\hline Predictor (Attitude) & Response (Behavior) & p-value & $\begin{array}{l}\text { Relationship } \\
\text { Direction }\end{array}$ \\
\hline $\begin{array}{l}\text { Q18- Care about } \\
\text { environment }\end{array}$ & $\begin{array}{l}\text { Q10f- Talking to neighbors } \\
\text { about restoration }\end{array}$ & 0.0846 & + \\
\hline Q16- Connection to site & $\begin{array}{l}\text { Q10i- Advocating for natural } \\
\text { areas }\end{array}$ & 0.0329 & + \\
\hline $\begin{array}{l}\text { Q17- Doing work to } \\
\text { socialize }\end{array}$ & $\begin{array}{l}\text { Q10i- Advocating for natural } \\
\text { areas }\end{array}$ & 0.0921 & - \\
\hline
\end{tabular}


Ownership Level- Predicting volunteer attitudes by reported behaviors

\begin{tabular}{|l|l|l|l|}
\hline Predictor (Behavior) & Response (Attitude) & p-value & $\begin{array}{l}\text { Relationship } \\
\text { Direction }\end{array}$ \\
\hline $\begin{array}{l}\text { Q10i- Advocating for } \\
\text { natural areas }\end{array}$ & Q16- Connection to site & 0.034 & + \\
\hline $\begin{array}{l}\text { Q10e- Treating yard as } \\
\text { wildlife habitat }\end{array}$ & $\begin{array}{l}\text { Q17- Doing work to } \\
\text { socialize }\end{array}$ & 0.0087 & - \\
\hline $\begin{array}{l}\text { Q10e- Treating yard as } \\
\text { wildlife habitat }\end{array}$ & $\begin{array}{l}\text { Q18- Care about } \\
\text { environment }\end{array}$ & 0.0346 & + \\
\hline $\begin{array}{l}\text { Q10f- Talking to neighbors } \\
\text { about restoration }\end{array}$ & $\begin{array}{l}\text { Q18- Care about } \\
\text { environment }\end{array}$ & 0.0741 & + \\
\hline $\begin{array}{l}\text { Q10g- Conserving water in } \\
\text { yard/home }\end{array}$ & $\begin{array}{l}\text { Q21- Enjoying nature- } \\
\text { based education }\end{array}$ & 0.0013 & + \\
\hline
\end{tabular}

Empowerment Level- Predicting volunteer behaviors by reported attitudes

\begin{tabular}{|l|l|l|l|}
\hline Predictor (Attitude) & Response (Behavior) & p-value & $\begin{array}{l}\text { Relationship } \\
\text { Direction }\end{array}$ \\
\hline $\begin{array}{l}\text { Q17- Doing work to } \\
\text { socialize }\end{array}$ & $\begin{array}{l}\text { Q10a- Planting natives at } \\
\text { home }\end{array}$ & 0.0957 & - \\
\hline Q16- Connection to site & $\begin{array}{l}\text { Q10f- Talking to neighbors } \\
\text { about restoration }\end{array}$ & 0.0103 & + \\
\hline $\begin{array}{l}\text { Q17- Doing work to } \\
\text { socialize }\end{array}$ & $\begin{array}{l}\text { Q10f- Talking to neighbors } \\
\text { about restoration }\end{array}$ & 0.0205 & - \\
\hline $\begin{array}{l}\text { Q24- My work } \\
\text { contributes to } \\
\text { environmental solutions }\end{array}$ & $\begin{array}{l}\text { Q10f- Talking to neighbors } \\
\text { about restoration }\end{array}$ & 0.0644 & + \\
\hline $\begin{array}{l}\text { Q25- Environmentalist } \\
\text { Identity }\end{array}$ & $\begin{array}{l}\text { Q10f- Talking to neighbors } \\
\text { about restoration }\end{array}$ & 0.0165 & + \\
\hline $\begin{array}{l}\text { Q21- Enjoying nature- } \\
\text { based education }\end{array}$ & $\begin{array}{l}\text { Q10i- Advocating for natural } \\
\text { areas }\end{array}$ & 0.0178 & + \\
\hline $\begin{array}{l}\text { Q23- Paying attention to } \\
\text { environmental issues }\end{array}$ & $\begin{array}{l}\text { Q10i- Advocating for natural } \\
\text { areas }\end{array}$ & 0.0395 & + \\
\hline
\end{tabular}


Empowerment Level- Predicting volunteer attitudes by reported behaviors

\begin{tabular}{|c|c|c|c|}
\hline Predictor (Behavior) & Response (Attitude) & $p$-value & $\begin{array}{l}\text { Relationship } \\
\text { Direction }\end{array}$ \\
\hline $\begin{array}{l}\text { Q10e- Treating yard as } \\
\text { wildlife habitat }\end{array}$ & Q16- Connection to site & 0.0018 & - \\
\hline $\begin{array}{l}\text { Q10f- Talking to neighbors } \\
\text { about restoration }\end{array}$ & Q16- Connection to site & $1.69 \times 10^{-5}$ & + \\
\hline $\begin{array}{l}\text { Q10h- Using parks in free } \\
\text { time }\end{array}$ & Q16- Connection to site & 0.00024 & + \\
\hline $\begin{array}{l}\text { Q10h- Using parks in free } \\
\text { time }\end{array}$ & $\begin{array}{l}\text { Q17- Doing work to } \\
\text { socialize }\end{array}$ & 0.0206 & - \\
\hline $\begin{array}{l}\text { Q10i- Advocating for } \\
\text { natural areas }\end{array}$ & $\begin{array}{l}\text { Q17- Doing work to } \\
\text { socialize }\end{array}$ & 0.0671 & + \\
\hline $\begin{array}{l}\text { Q10c- Using green } \\
\text { household products }\end{array}$ & $\begin{array}{l}\text { Q18- Care about } \\
\text { environment }\end{array}$ & 0.0814 & - \\
\hline $\begin{array}{l}\text { Q10e- Treating yard as } \\
\text { wildlife habitat }\end{array}$ & $\begin{array}{l}\text { Q18- Care about } \\
\text { environment }\end{array}$ & 0.0516 & + \\
\hline $\begin{array}{l}\text { Q10g- Conserving water in } \\
\text { yard/home }\end{array}$ & $\begin{array}{l}\text { Q18- Care about } \\
\text { environment }\end{array}$ & 0.0174 & + \\
\hline $\begin{array}{l}\text { Q10i- Advocating for } \\
\text { natural areas }\end{array}$ & $\begin{array}{l}\text { Q18- Care about } \\
\text { environment }\end{array}$ & 0.0264 & + \\
\hline $\begin{array}{l}\text { Q10d- Using pesticide in } \\
\text { yard }\end{array}$ & $\begin{array}{l}\text { Q19- Liking community } \\
\text { efforts }\end{array}$ & 0.0151 & - \\
\hline $\begin{array}{l}\text { Q10i- Advocating for } \\
\text { natural areas }\end{array}$ & $\begin{array}{l}\text { Q20- Interest in volunteer } \\
\text { leadership position }\end{array}$ & 0.0162 & + \\
\hline $\begin{array}{l}\text { Q10i- Advocating for } \\
\text { natural areas }\end{array}$ & $\begin{array}{l}\text { Q21- Enjoying nature- } \\
\text { based Education }\end{array}$ & 0.0023 & + \\
\hline $\begin{array}{l}\text { Q10a- Planting natives at } \\
\text { home }\end{array}$ & $\begin{array}{l}\text { Q22- Interest in restoration } \\
\text { ecology }\end{array}$ & 0.0229 & + \\
\hline $\begin{array}{l}\text { Q10b- Removing invasive } \\
\text { species at home }\end{array}$ & $\begin{array}{l}\text { Q22- Interest in restoration } \\
\text { ecology }\end{array}$ & 0.0109 & - \\
\hline $\begin{array}{l}\text { Q10g- Conserving water in } \\
\text { yard/home }\end{array}$ & $\begin{array}{l}\text { Q22- Interest in restoration } \\
\text { ecology }\end{array}$ & 0.0128 & + \\
\hline $\begin{array}{l}\text { Q10i- Advocating for } \\
\text { natural areas }\end{array}$ & $\begin{array}{l}\text { Q22- Interest in restoration } \\
\text { ecology }\end{array}$ & 0.0105 & + \\
\hline $\begin{array}{l}\text { Q10c- Using green } \\
\text { household products }\end{array}$ & $\begin{array}{l}\text { Q23- Paying attention to } \\
\text { environmental issues }\end{array}$ & 0.0131 & - \\
\hline $\begin{array}{l}\text { Q10g- Conserving water in } \\
\text { yard/home }\end{array}$ & $\begin{array}{l}\text { Q23- Paying attention to } \\
\text { environmental issues }\end{array}$ & 0.0498 & + \\
\hline $\begin{array}{l}\text { Q10d- Using pesticide in } \\
\text { yard }\end{array}$ & $\begin{array}{l}\text { Q24- My work contributes } \\
\text { to environmental solutions }\end{array}$ & 0.0656 & - \\
\hline $\begin{array}{l}\text { Q10f- Talking to neighbors } \\
\text { about restoration }\end{array}$ & $\begin{array}{l}\text { Q24- My work contributes } \\
\text { to environmental solutions }\end{array}$ & 0.006 & + \\
\hline $\begin{array}{l}\text { Q10h- Using parks in free } \\
\text { time }\end{array}$ & $\begin{array}{l}\text { Q24- My work contributes } \\
\text { to environmental solutions }\end{array}$ & 0.0317 & + \\
\hline
\end{tabular}




\section{Appendix F: Human Subjects Approval}

Human Subjects Research Review Committee

Post Office Box $751 \quad 503-725-4288$ tel

Portland, Oregon 97207-0751 503-725-8170 fax

hsrrc@lists.pdx.edu

November 10, 2011

To:

Marion Dresner

From:

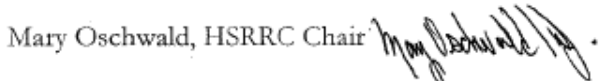

Re:

HSRRC renewal of approval for your project titled, "ULTRA-EX Education" (HSRRC Proposal \# 101564).

As part of the Committee's continuing review, the Human Subjects Research Review Committee has reviewed your above referenced project for compliance with PSU and DHHS policies and regulations on the protection of human subjects.

The Committee is satisfied that your provisions for protecting the rights and welfare of all subjects participating in the research are adequate Your project is renewed and this approval will expire on December 10, 2012. Please note the following policies:

1. If the project continues beyond the expiration date, the investigator must again submit a Continuing Review Report form two months before the expiration date. The form is available at www.rsp.pdx.edu/compliance_human.php and in the Office of Research \& Strategic Partnerships (RSP).

2. To add this project's continuing review to the HSRRC/IRB meeting agenda, please refer to the HSRRC/IRB meeting schedule. Submit the report, and 8 copies, by the submission deadline that is approximately two months before the project's e expiration date. The HSRRC/IRB needs two months to do a continuing review of the project, so it is extremely important that you meet the committee's submission deadline.

3. If this project finishes before the expiration date, please contact the HSRRC so that the file can be closed and records updated. It is the investigator's responsibility to kecp the approval status current. If the project's approval expires while the project is active, the investigator must complete a new application and submit it for a new HSRRC review. In addition, any data collected after the expiration date cannot be used in the research. Please don't let this happen!

If you have questions or concerns, please contact the HSRRC in the Office of Research and Strategic Partnerships (RSP), 503-725-4288, Market Center Building, Room 620.

Cc: Linda George 